RACAR : Revue d'art canadienne

Canadian Art Review

\title{
“T'Other Emily:” Emily Carr, the Modern Woman Artist and Dilemmas of Gender
}

\section{Gerta Moray}

Volume 26, numéro 1-2, 1999

Postures et impostures de l'artiste moderne

Myths of the Modern Artist: Exposing the Pose

URI : https://id.erudit.org/iderudit/1071551ar

DOI : https://doi.org/10.7202/1071551ar

Aller au sommaire du numéro

\section{Éditeur(s)}

UAAC-AAUC (University Art Association of Canada | Association d'art des universités du Canada)

\section{ISSN}

0315-9906 (imprimé)

1918-4778 (numérique)

Découvrir la revue

Citer cet article

Moray, G. (1999). “T’Other Emily:” Emily Carr, the Modern Woman Artist and Dilemmas of Gender. RACAR : Revue d'art canadienne / Canadian Art Review, 26(1-2), 73-90. https://doi.org/10.7202/1071551ar

\section{Résumé de l'article}

La carrière d'Émily Carr, tout comme les thèmes artistiques qu'elle choisit de développer, étaient pour le moins inusuels chez une femme artiste du début du $20^{\mathrm{e}}$ siècle. Comme nous le savons, elle rejeta les principes de la trop convenable peinture féminine qui se faisait à Paris à l'époque et qu'endossaient ses contemporaines en Colombie-Britannique, pour se lancer dans les techniques novatrices du Fauvisme, ainsi que dans un ambitieux projet de catalogage des villages aborigènes isolés au fin fond de la Côte Ouest et de leurs totems. Cet article se penche sur l'évidence présente dans la peinture de Carr et dans ses écrits inspirés de sa vie marquée de confrontations et de tensions, conséquence de son refus de se plier à la condition féminine de son temps. En raison des rapports problématiques que Carr entretint très tôt avec les hommes, ses attitudes prirent modèle sur le " complexe de masculinité » tel que décrit par Karen Horney. En raison de son style avant-gardiste, sa peinture fut étiquetée de " virile ", malgré le fait que, pour compenser son rejet du rôle féminin trop répressif, elle privilégia l'imagerie célébrant le côté maternel des amérindiennes, ainsi que les forces péremptoires de Dzonokwa, figure féminine légendaire du peuple Kwakwaka’wakw. Les expériences éprouvantes qu'elle vécut sont de plus reflétées dans ses lettres et ses récits sous la forme de personnages divergents.
Tous droits réservés @ C UAAC-AAUC (University Art Association of Canada | Association d'art des universités du Canada), 2002
Ce document est protégé par la loi sur le droit d'auteur. L'utilisation des services d'Érudit (y compris la reproduction) est assujettie à sa politique d'utilisation que vous pouvez consulter en ligne.

https://apropos.erudit.org/fr/usagers/politique-dutilisation/ 


\title{
“T’Other Emily:” Emily Carr, the Modern Woman Artist and Dilemmas of Gender*
}

\author{
GERTA MORAY, UNIVERSTTY OF GUELPH
}

Résumé
a carrière d'Émily Carr, tout comme les thèmes artistiques qu'elle
choisit de développer, étaient pour le moins inusuels chez une
femme artiste du début du $20^{e}$ siècle. Comme nous le savons,
elle rejeta les principes de la trop convenable peinture féminine qui
se faisait à Paris à l'époque et qu'endossaient ses contemporaines en
Colombie-Britannique, pour se lancer dans les techniques novatrices
du Fauvisme, ainsi que dans un ambitieux projet de catalogage des
villages aborigènes isolés au fin fond de la Côte Ouest et de leurs
totems. Cet article se penche sur l'évidence présente dans la pein-
ture de Carr et dans ses écrits inspirés de sa vie marquée de confron-
tations et de tensions, conséquence de son refus de se plier à la condition féminine de son temps. En raison des rapports problématiques que Carr entretint très tôt avec les hommes, ses attitudes prirent modèle sur le «complexe de masculinité » tel que décrit par Karen Horney. En raison de son style avant-gardiste, sa peinture fut étiquetée de "virile », malgré le fait que, pour compenser son rejet du rôle féminin trop répressif, elle privilégia l'imagerie célébrant le côté maternel des amérindiennes, ainsi que les forces péremptoires de Dzonokwa, figure féminine légendaire du peuple Kwakwaka'wakw. Les expériences éprouvantes qu'elle vécut sont de plus reflétées dans ses lettres et ses récits sous la forme de personnages divergents.
How nice men are, so much nicer than I thought once long agoe [sic]. I used to be a man hater once, and now I have far more men than women friends. (Tell me, why did you in writing say my work was very masculine? I have often wondered). ${ }^{1}$

T his comment, made by Canadian landscape painter and writer Emily Carr (1871-1945) in a letter to her editor and friend Ira Dilworth in 1942, signals the contradictions that she experienced as a woman who was also a modernist artist. I shall examine in this paper how Carr negotiated these conflicting roles while working in a colonial environment during the first part of the twentieth century. To do so I shall draw on biographical material and on reflections on gender found in her writings, but above all I shall be concerned with an analysis of Carr's artistic production and of her situation as a painter. Feminist literary critics have recently begun to explore Carr's subjectivity as it is seen in aspects of her writings, in her language and imagery, and in her relationship to literary genres. ${ }^{2}$ Yet Carr's engagement with writing began relatively late in her life, and her stories were shaped for publication only towards its end. ${ }^{3}$ In her formative years, and throughout the many vicissitudes of her adult life, she was dedicated to making a career in the visual arts. Here she confronted gender discrimination in the discourses of art education and of art criticism, and faced the social constraints prescribed by the roles for women of her race and class. Anne M. Wagner has proposed that we "consider the artist's painting or sculpture as the material site of her voice." She remarks that "making art, 'as a woman' seems best understood as a historically contingent act with different cultural weight and allure at different moments in time. Femininity can be assigned as well as claimed, avoided as well as celebrated, with an act of negation potentially as eloquent as affirmation." "I shall show how Carr, in her paintings, claimed stylistic territory and types of content that were at the time coded as masculine, while she found ways within them to assert a female identity and to explore concerns that arose from her experience as woman. Carr's artistic career and the style and imagery of her paincings can be examined as arenas where she positioned herself in relation to the prevailing constructs both of gender and of the modern artist.

The situation is complicated by the fact that Carr has been mythologized as a Canadian cultural icon, a process that began in 1927 with the Exhibition of Canadian West Coast Art, Native and Modern, at the National Gallery. This exhibition was part of an eastern Canadian drive to build a national culture. In it were featured, alongside works by modern Canadian painters, the artifacts of the Northwest Coast Native peoples, presented as a "primitive" art form that was distinctively Canadian and upon which modern artists and designers were encouraged to draw. It also included paintings of Northwest Coast Native villages and totem poles that Emily Carr had made fifteen years earlier in an attempt to document and defend the traditional cultures of the First Nations of the coast which were then threatened by the rapid influx of settlers. ${ }^{5}$ Her work had not been well received in British Columbia at the time she made it, but in the national arena her reputation was constructed as a "gone native" figure who had achieved a deep understanding of Native traditions. As her landscape painting developed from the late 1920s, so did the legend that Carr had learned to express the unique qualities of the Northwest Coast landscape by "living with the Indians."

An important consequence of the 1927 exhibition for Carr was that it brought her into the circle of the Group of Seven, whose landscape paintings were seen as the core of a "Canadian art movement." The painters of the Group had represented the Canadian Northland as a wild, unspoiled domain of nature. This so-called wilderness was currently the scene of rapid resource-industry expansion, and the Group's expeditions there 
were seen as a similar, though spiritual, quest. They were "a new type of artist; one who divests himself of the velvet coat and flowing tie of his caste, puts on the outfit of the bushwhacker and prospector; closes with his environment; paddles, portages and makes camp; sleeps in the out-of-doors under the stars; climbs mountains with his sketch box on his back." ${ }^{6}$ The defenders of the Group deployed a rhetoric that emphasized the "virility" of modern art. This idea echoed a current of criticism in Europe that had associated vanguard movements such as Realism, and even more so Cubism, Futurism and Constructivism, wich principles of formal innovation, political combativeness and virility. In Canada, the trope of the artist as bushwhacker and prospector gave a local twist to the link between modern art and assertive masculinity. The ambition Emily Carr conceived during her Vancouver days (1906-13) to find a way of rendering the tremendous scale of the British Columbia landscape and to make an artistic record of remote, "uncivilized" northern Native villages, as well as her engagement in France with an experimental modern painting idiom, had already then been seen as pushy and excessive in a woman. ${ }^{7}$ Her elevation alongside the Group of Seven was thus not the first time that she was perceived as entering a masculine domain.

\section{Dzonokwa!}

I shall start by considering an important group of paintings which Carr made at this crucial turning point in her life, the period 1928-32, when she first received national recognition as a modern artist. As Carr attained this long-delayed success, we find her producing a series of paintings in which monumental female images appear in the guise of Native carvings. Why did she paint these particular images, and just at this time? A painting that poses the issue very dramatically is Guyasdoms d'Sonoqua of 1928-30 in the collection of the Art Gallery of Ontario (fig. 1). This arresting, even shocking image shows a Kwakwaka'wakw ${ }^{8}$ carving of the wild woman of the forest, a mythological being represented as a naked female with the face of a mask, her lips pursed to utter a cry; with, in Carr's words, "her arms flung wide in a circling, compelling movement, ... her breasts two cagle-heads, fiercely carved." "It is one of several paintings that Carr began early in 1928, on her return from the journey she had made to eastern Canada to attend the opening of the Exhibition of Canadian West Coast Art, Native and Modern. ${ }^{10}$ Carr's response to her meeting with the Group of Seven, and to their paintings, had been double-edged. Her journal entries reveal her sometimes ecstatic and awestruck, while simultaneously filled with a sense of her own inadequacy and of the outof-dateness of her own work, and sometimes stepping back coolly and professionally to appraise the stylistic strengths or weaknesses she found in canvases by various members of the
Figure I. Emily Carr, Guyasdoms d'Sonoqua, 1928-30. Oil on canvas, $100.3 \times 65.4 \mathrm{~cm}$. Art Gallery of Ontario, gift of the Albert H. Robson Memorial Subscription Fund, 1942 (Photo: Art Gallery of Ontario).

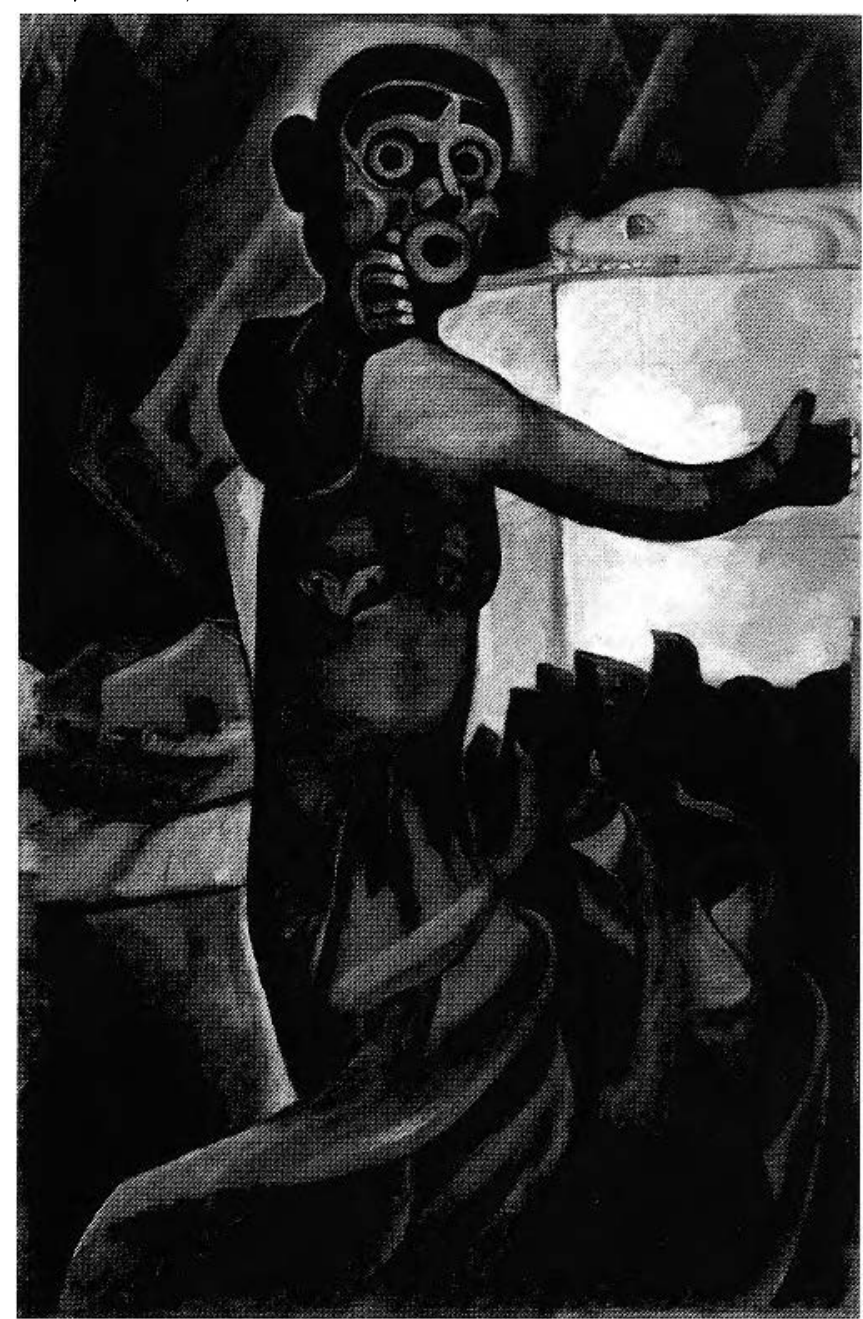

Group. On the one hand, then, we have the statement of ecstatic abandon, the famous cadenza in her journals:

Oh, God, what have I scen? Where have I been? Something has spoken to the very soul of me, wonderful, mighty, not of this world. Chords way down in me have been touched. Dumb notes have struck chords of wonderful tone. Something has called ouc of somewhere. Something in me is rrying to answer.

It is surging through my whole being, the wonder of it all, like a great river rushing on, dark and turbulent, rushing and irresistible, carrying me away on its wild swirl like a helpless little bundle of wreckage. Where, Where? Oh, these men, this Group of Seven, what have they created? - a world stripped of earthiness, shorn of fretring details, purged, purified: a naked soul, pure and unashamed; lovely spaces filled with wonderful serenity. ${ }^{11}$ 
And again:

These men are very interesting and big and inspiring. ... I know they are building an art worthy of our great country, and I want to have my share, to put in a little spoke for the West, one woman holding up my end. ${ }^{12}$

At the same time Carr is full of misgivings about her own status:

I wonder if these men feel as I do that there is a common chord struck between us. No, I don't believe they feel so toward a woman. ${ }^{13}$

Carr's language throughout these passages of her journal emphasizes her awareness of her own difference, not only in terms of provincialism and lesser success, but notably also of gender. Finally, Carr reassures herself:

I felt my work looked dead and dull, but they all say I have more of the spirit of the Indian than the others. ${ }^{14}$

She adds:

Perhaps his [A.Y. Jackson's] haven't quite the love in them of the people and the country that mine have. How could they? $\mathrm{He}$ is not a Westerner and I took no liberties. I worked for history and cold fact. Next time I paint Indians I'm going off on a tangent tear. ... Oh the West! I'm of it and I love it. ${ }^{15}$

The painting Guyasdoms d'Sonoqua comes at the beginning of Carr's "tangent tear." As the quotations make clear, Carr felt empowered by her recognition as the accredited representative of western Canadian art, and she resolved as a result to create interpretations of what she believed to be the meanings and themes underlying Native carvings. Through this subject matter, and through her return to Victoria, British Columbia, with its relative isolation, Carr could make a virtue of her otherness, of her gender, of her geographic territory, and of her experience of Native culture. Two themes which Carr now "discovered" in aboriginal imagery, and developed in her paintings of 1928-32 as I shall show, were those of a frightening, assertive and ambiguous femininity, and of a nurturing and powerful motherhood.

Carr's Guyasdoms d'Sonoqua shows the carved figure of a naked female. It is an image that Carr took from one of her early field sketches of 1912 (fig. 2). She had already exhibited it in her major Vancouver exhibition of documentary paintings of Native villages in 1913, but she had done so without turning the rough sketch either into a finished studio watercolour or into an oil. This was an anomaly in her practice at the time, and
Figure 2. Emily Carr, D'Sonoqua, 1912. Watercolour on two sheets of paper, joined, $83.8 \times 47$ cm. British Columbia Archives (Photo: British Columbia Archives).

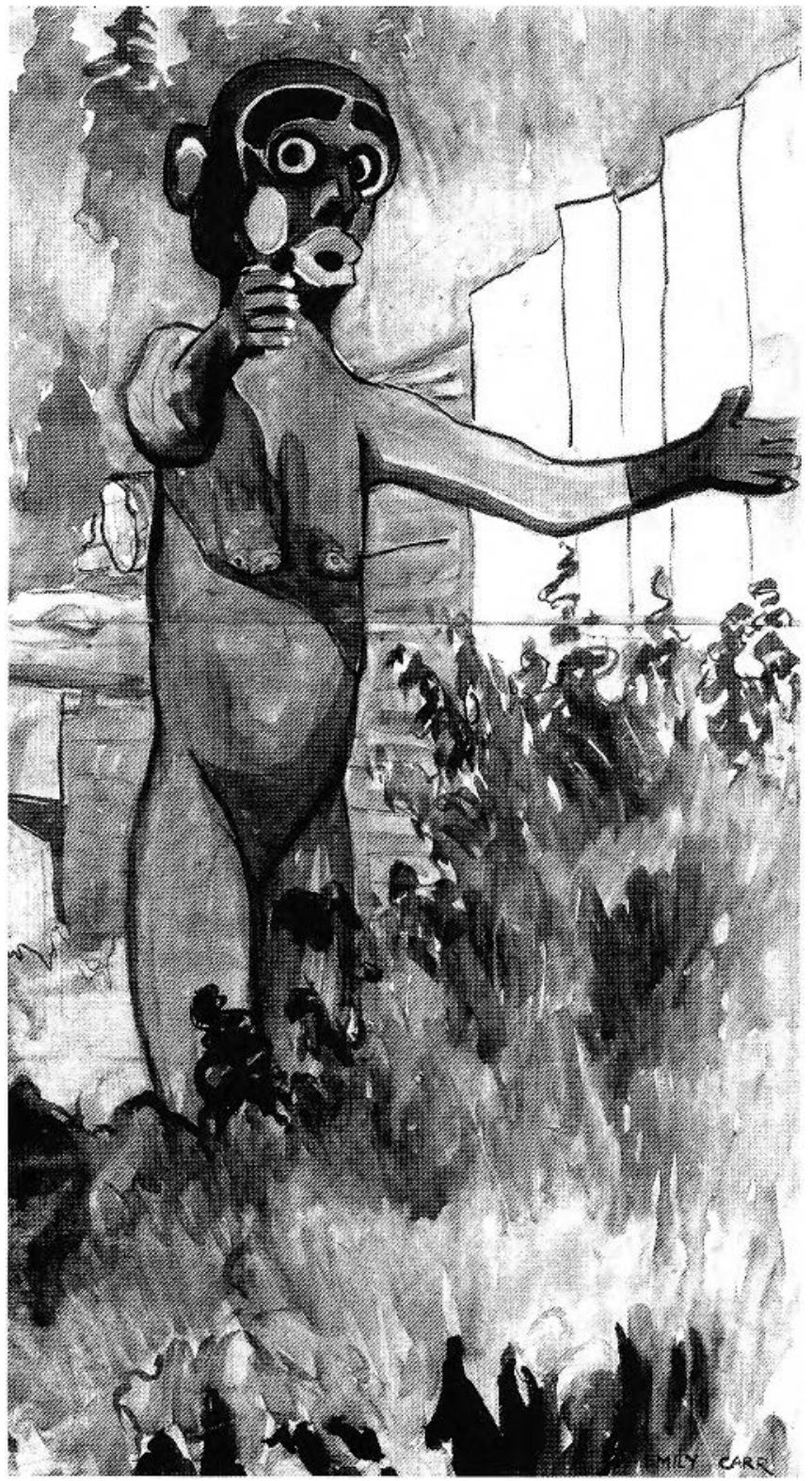

her early hesitation may best be explained by Carr's extreme modesty and inhibition about the female body. ${ }^{16}$ Carr herself described her upbringing as that of a "prim prude." She and her sisters "had never been taught to think of our naked bodies as something beautiful, only as something indecent, something to be hidden." 17 Confrontation with the female nude at life classes had been a crisis for her, and at the California School of Design in San Francisco she had refused to attend them. Later, Carr had accepted the doctrine that the nude (as opposed to the naked) was the epitome of art, and at the Westminster School of Art in London she had found in the model "only loveliness - a 
Figure 3. Emily Carr. Zunoqua, 1930. Watercolour on paper, $44.5 \times 32.1 \mathrm{~cm}$. Vancouver Art Gallery (Photo: Trevor Mills).

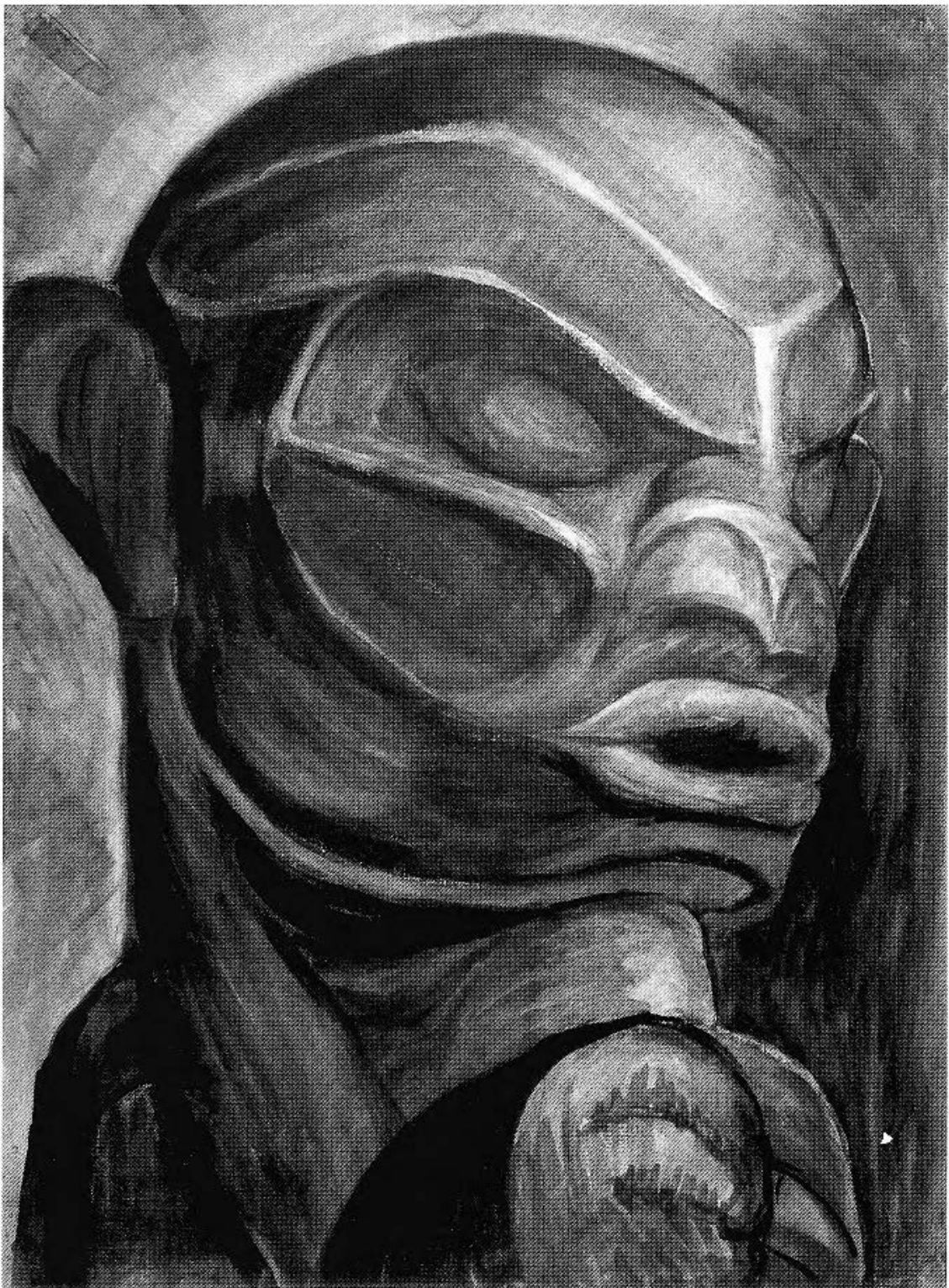

uninhibited primitive sensuality. Carol Duncan has described this kind of painting as mediating fantasies of male sexual domination over women, and allowing malc patrons to share by proxy the presumed sexual and aesthetic freedom of the artist. ${ }^{19}$ Carr described her own reaction to seeing her teacher's work: "Mr. Gibb's landscapes and still life delighted me - brilliant, luscious, clean. Against the distortion of his nudes I felt revolt." Carr was also made to feel her subordinate status as a woman in the art world of Paris. She quoted Gibb as saying, "You will be one of the painters, - women painters,' he modified, 'of your day.' 'That was high praise from Mr. Gibb! But he could never let me forget that I was only a woman. He would never allow a woman to compete with men." ${ }^{20}$

It is striking then that Carr should have selected the image of a nude female in 1928 as one of the first canvases to paint on her return from the east. Here Carr takes on the subject matter of the virile vanguard artist, but she changes its mode of address. The female figure is active, angry, powerful. The hesitantly rendered Dzonokwa of the sketch becomes forcefully three-dimensional in the painting and almost projects from the picture plane towards the viewer. Carr creates tension between the volume of the figure and the flatness of the canvas's surface: a geometric structure locks the figure in place between the flattened planes of the buildings and the faceted forms of vegetation picked out by a schematic play of light. Carr's style of painting here is more assertively abstract than the concurrent work of glad, life-lit body, a woman proud of her profession, proud of her shapely self, regal, illuminated, vital, highposed above our clothed insignificance." 18 However, while Carr described the atmosphere of her London life-class as one of "sacred hush," she was aware that in the provincial environment of North America the nude was connected only with "loose life in wicked Paris," and that it could never figure in her own publicly exhibited art. In Paris, through her teachers Henry Phclan Gibb and John Duncan Fergusson, she had encountered the figure painting of vanguard artists in the orbit of Gauguin and of the Fauves and Cubists (fig. 5). The female nudes in the works of these artists were often highly stylized in ways that evoked violence or the Group of Seven, and her eclectically analytical approach draws upon the formal lessons both of the Parisian Cubists and of Northwest Coast Native carvers, whose work she described at the time as "by far the most 'modern' in spirit of anything in western Canada." 21 Viewed in the context of her recent encounter with the Group of Seven, the painting Guyasdoms d'Sonoqua entails a defiant affirmation both of Carr's commitment to modernism and of her difference. That difference turns upon her gender and on her self-identification with Native culture, to which Carr attributed a privileged relation to modernism in its style and a special acknowledgment of women's powers through its imagery. 
Figure 4. Emily Carr, Zunoqua of the Cat Village, 1930. Oil on canvas, $112.2 \times 70.6 \mathrm{~cm}$. Vancouver Art Gallery (Photo: Trevor Mills).

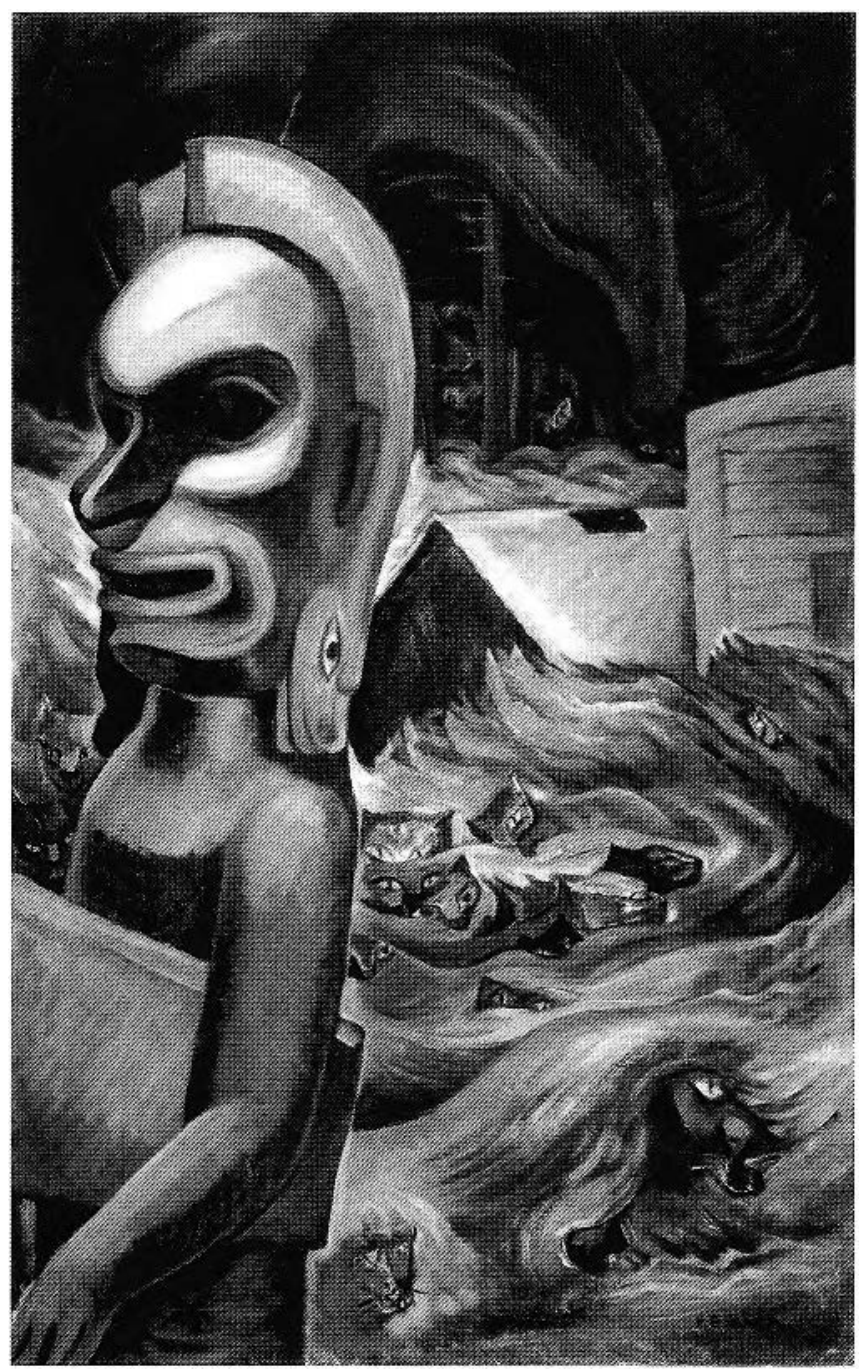

Such a reading is reinforced by the fact that in the following years Carr deliberately sought out female images for her paintings of Northwest Coast Native motifs. Eight major oil paintings of the next three years would represent carved female figures. Among these we find several further Dzonokwa images, painted during and after a trip Carr took to the Kwakwaka'wakw villages at the north end of Vancouver Island in August 1930. Two of them are large Dzonokwa watercolours made at Alert Bay, both showing the figure on a memorial pole recently erected in the village cemetery there (fig. 3). ${ }^{22}$ Another image, Zunoqua of the Cat Village, was developed by Carr both as a large charcoal drawing and as a large canvas (fig. 4). It shows a carved housepost in a village on Quattishe Island in Quatsino Sound, one that was probably not in fact a female figure, but which Carr took as a Dzonokwa. ${ }^{23}$

The wild woman, then, was a motif that fascinated Carr from her first encounter, and after 1927 provided her with a figure for her own projections. In her writings Carr attributes an intense and decisive influence in her psychic development to her relationship with this ambiguous figure - to "the spirit of D'Sonoqua ... and what she did to me." ${ }^{24}$ This is conveyed in the story "D'Sonoqua," in Klee Wyck, both through Carr's vivid descriptions of the encounters and through the mythical tone she gives to them. She begins the tale by recalling her first meeting with Dzonokwa at a Kwakwaka'wakw village in 1912. Carr is set down on an island at a temporarily deserted village. As she battles her way along the slippery village boardwalk through stinging nettles taller than her head, she falls headlong and, looking up, has the "terrifying" experience of finding "the great wooden image towering above me." Carr notes that after this, "the fierce wooden image often came to me, both in my waking and in my sleeping." 25 The story continues by telescoping events widely separated in Carr's life. Carr describes two other Dzonokwa figures that she saw on her sketching trip in 1930. The first of these suggested to Carr "power, weight, domination." Carr wrote of this figure,

I knew her by the stuck-out ears, shouting mouth, and deep eye-sockets. ... She was unpainted, weather-worn, suncracked, and the arms and hands seemed to hang loosely. The fingers were thrust into the carven mouths of two human heads, hold crowns down. From behind, the sun made unfathomable shadows in eye, cheek and mouth. Horror tumbled out of them. ${ }^{26}$

Carr uses these first two frightening encounters to lead on to a cathartic experience in which Dzonokwa is revealed as not necessarily malign. She questions a Native man she meets in the village about the "wild woman of the woods:"

"What does she do?"

"She steals children."

"To eat them?"

"No, she carries them to her caves.... When she cries

'OOO-oo-oo-oeo', Indian mothers are too frightened to move. They stand like trees and the children go with D'Sonoqua."

"Then is she bad?"

"Sometimes bad ... sometimes good." 27

This account of Dzonokwa's dual nature echoes significant elements of Carr's own picture of herself. In her autobiography Growing Pains, she portrays her contrary nature as a headstrong child, intensely loving but uncontrollably naughty. ${ }^{28}$ The girl Emily had longed to run off into the woods, and as a woman she would make it her career to do so. When Carr became an art 
Figure 5. William Henry Phelan Gibb, Three Graces, c. 1909. Oil on cardboard, $174 \times 99 \mathrm{~cm}$. Lucy Wertheim Bequest Collection, Towner Art Gallery, Eastbourne, England (Photo: Towner Art Gallery).

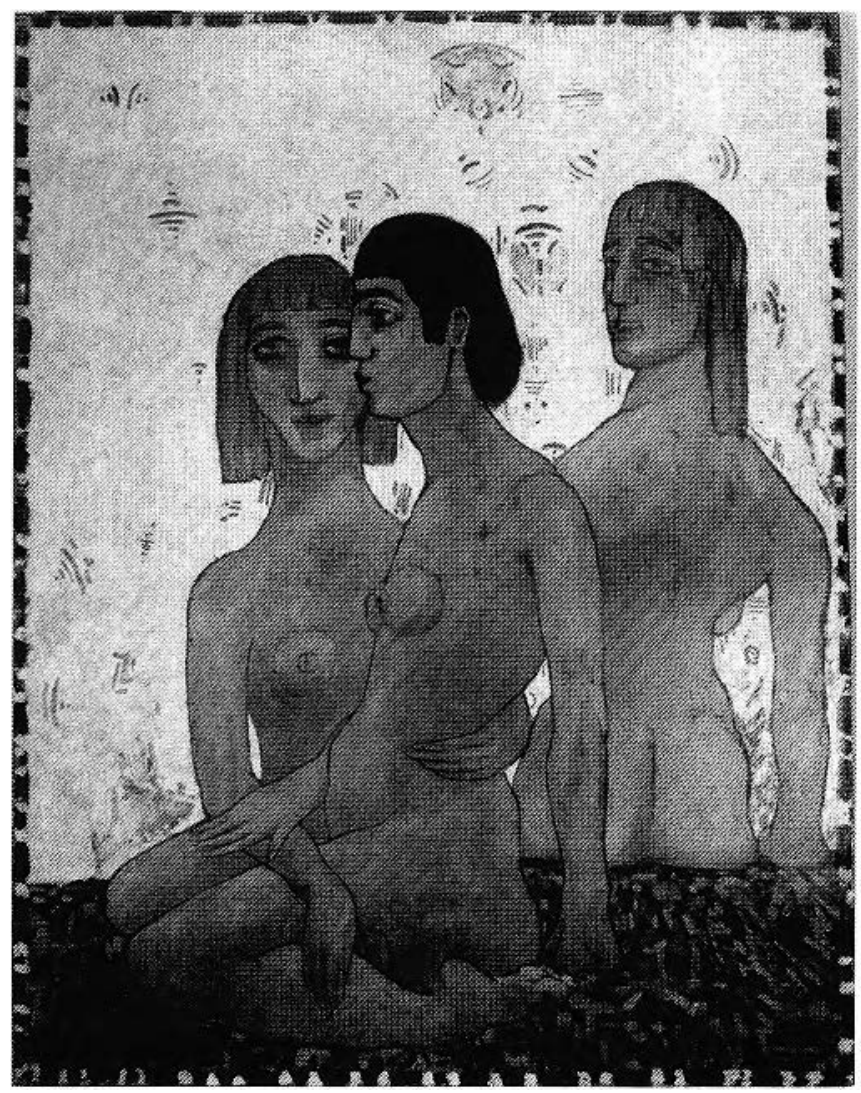

teacher, she led her pupils along railroad tracks or back lanes for sketching classes, to the horror of their protective parents. ${ }^{29}$ In the Dzonokwa figure she seems to have found both a mentor and a self-image, one as ambivalent as she felt herself to be. In a Freudian tradition we may see Carr's disturbing Guyasdoms d'Sonoqua as the image of a powerful phallic woman, one who covers over the threatening implications of the woman's supposed castration. ${ }^{30}$ Another professional woman in Carr's circle at this time, her friend Erna Gunther, the Washington University anthropologist, seems to have formed a similar identification; she signed herself "Zunokwa" in letters. ${ }^{31}$

In Carr's story, Dzonokwa finally turns into a powerful and benign persona, becoming a guardian spirit who offers her protection from her fears. The 1930 painting, Zunoqua of the Cat Village, (fig. 4) embodies this positive aspect, which is made explicit in the third encounter found in the story. Carr is once again put ashore alone in a temporarily deserted Kwakwaka'wakw village on the northern shores of Vancouver Island:

An eagle flew out of the forest, circled the village, and flew back again

Once again I broke silence, calling after him, "Tell
D'Sonocua -" and curning, saw her close, towering above me in the jungle.

Like the D'Sonoqua of the other villages she was carved into the bole of a red cedar tree. ...

She appeared to be neither wooden nor stationary, but a singing spirit, young and fresh, passing through the jungle. No violence coarsened her; no power domineered to wither her. She was graciously feminine....

I sat down to sketch. What was the noise of purring and rubbing going on about my feet? Cats. ... They jumped into my lap and sprang to my shoulders. They were real and very feminine.

There we were - D'Sonoqua, the cats and I - the woman who only a few moments ago had forced herself to come behind the houses in trembling fear of the "wild woman of the woods" - wild in the sense that the forest creatures are wild - shy, untouchable. ${ }^{32}$

The terrifying Dzonokwa of Carr's early encounter is here succeeded by a gracious, beneficent, but still powerful female figure through whom nature is partially exorcised of fear, and feminized. Carr's own self-image again comes to mind with the adjectives "wild - shy, untouchable."

This gracious image of Dzonokwa recalls Carr's descriptions of her mother, whom she represents as tolerant of Carr's wildness and who, after a traumatic quarrel between Emily and her father, took her outside the confines of her father's cultivated garden to picnic in the woods. ${ }^{33}$ By the end of the story, Carr has achieved union with Dzonokwa, the cats and the forest. The story can be read as a quest narrative, and more specifically as Carr's vision quest, her initiation into secret realms (the forest) and into an appropriate identity for herself as a female who crosses the boundaries of femininity prescribed by her culture. ${ }^{34}$

\section{"Feminine painting"}

If we turn to Carr's early training and to an earlier set of her images, we find that from the beginning of her career she confronted a set of gender definitions that presented women artists with distinct constraints in their modes of artistic production. Tamar Garb's study of the Union des Femmes Peintres et Sculpteurs, the organizacion of women artists established in Paris in 1881, shows the constraints that professionally ambitious late nineteenth-century women placed upon themselves, even when they were determined to go beyond the types of painting traditionally sanctioned for them (still life, flower painting and portraits) and to succeed in areas considered beyond their competence. ${ }^{35}$ These women campaigned for the right to admission to the state-run art academy but not for the suffrage, and they 
faced the exacerbated public debate of the time about the limits implied by women's gender. ${ }^{36}$ In 1891 the Union's first president, sculptor Madame Léon Bertaux, called on women artists to create l'art féminin and, in accord with their "feminine mission," to "invent that which consoles the heart, charms the mind and appeals to the eye." Her successor, Virginie DemontBreton, executed large-scale figure paintings, mainly depicting themes of female heroism and maternal devotion. Both invaded what was considered the masculine preserve of le grand art, which was thought to require intellectual capacities and a mastery over nature foreign to women. In their treatment of subject matter, however, Bertaux with her chaste and idealized nudes, and Demont-Breton with the "special feminine tenderness" of her history paintings, bowed to the essentialist gender assumptions of the time. ${ }^{37}$

All Emily Carr's own teachers at the California School of Design in San Francisco had been men, and most were trained in Paris and in the Beaux Arts tradition. ${ }^{38}$ At this school Carr took the usual classes in drawing from the antique, in still life, in flower painting, in portraiture, and in landscape painting. It was to the latter that she felt most strongly drawn. She subsequently destroyed almost all her work from this period, preserving only what had claims as a historical record: her 1890s ink drawings of Victoria, and her sketches of the Nuuchah-nulth village of Hiitats'un by Ucluelet, all done in the style of popular magazine travel illustration. ${ }^{39}$ Through her education, Carr was familiar with the modes of painting considered suitable for women, but she was interested in the more ambitious areas of landscape painting and of contemporary reportage.

Carr sought further training in England, where she continued to pursue her interest in landscape, and where she experienced a crisis in her vocation as an artist. As she confronted the fact that she had burned her boats in regard to marriage and to a conventional woman's role, and that her three years of exhausting overwork in the crowded and competitive art world there had brought her no professional discinction, she suffered a nervous breakdown and a lengthy illness. ${ }^{40}$ Her symptoms and treatment, as she describes them, closely correspond to those recorded at the time for many women whose aspirations to professional independence led to breakdowns in health. ${ }^{41}$ Women who rebelled against the expectations of the female domestic and sexual roles, as Elaine Showalter has shown, were often diagnosed as hysterics. Neurasthenia was considered to be a particular hazard of modernity, "especially among those in the professions and the higher walks of business life, who are in deadly earnest in the race for place and power." 42 Carr was hospitalized in what was for the times a progressive institution, one run entirely by and for women, but she was put through the standard remedies of the day for neurasthenia: total rest with a ban on all intellectual activity, followed by massage and enforced feeding. ${ }^{43}$

Her stay in England made Carr ill, but it also made possible her self-conscious identification with Canada as the land of great open spaces, of wild forests and Native "Indians," and as a place that offered new possibilities for an independent woman. In her autobiography, Carr expressed distress at the willingness of English women - those, anyway, whom Carr had met - to subordinate themselves to men and to marriage. "Why should everything be for the boys and men in England?" she asked a friend. "I'm glad I'm Canadian!" 44 In London she regaled friends with stories of the wildness of Vancouver Island and of her experience of visiting Native villages around the mission at Ucluelet on its west coast, and began to use as a nickname the Nuu-chah-nulth name "Klee Wyck," that she had been given at Ucluelet. ${ }^{45}$ She brought back from England a resolute professionalism and the confirmation of her identity as a colonial and a Canadian. She moved to Vancouver, now British Columbia's largest city, at the beginning of 1906, in search of more professional opportunities and a livelier art scene. Here she became a founding member of the British Columbia Fine Art Society and a frequent exhibitor, enjoying good press reception for her local landscapes, still-life and flower paintings, and occasional portrait and genre studies, all painted in an academic-naturalist style. During these years, 1907-12, which saw a boom in the expansion of the province's economy and settler base under Premier McBride, Carr conceived a far more ambitious project: she would travel to and document Kwakwaka'wakw, Haida and Gitksan villages on the fringes of white settlement.

Carr came to conceive this work as a civic project that would instruct the settler community and enrich her province. To accomplish this she pursued further training in Paris, then acknowledged as the most advanced art centre in the world, studying with Phelan Gibb, an admirer of Gauguin and friend of Matisse and Picasso, who introduced her to the Primitivist doctrine that the visual arts of non-European peoples had significant aesthetic qualities. ${ }^{46}$ She also drew on the ethnographic resources of the newly founded local museums in Vancouver and Victoria, whose collections she hoped her own work might complement.

With these activities, Carr set herself apart from other women artists of the time in British Columbia. This is very apparent when we compare Carr's work with that of two prominent contemporaries in British Columbia, Sophie Pemberton and Grace Judge. These women artists consistently cultivated acceptably feminine subject matter and an academically accomplished style, so that their work neither transgressed gender demarcations, nor risked the un-sexing which threatened the vanguard woman artist. Sophie Pemberton had displayed great talent during her training at the South Kensington School of 
Figure 6. Sophia Pemberton, Un Livre Ouvert, 1900. Oil on canvas, Art Gallery of Greater Victoria (Photo: Ken McAllister, for Art Gallery of Greater Victoria).

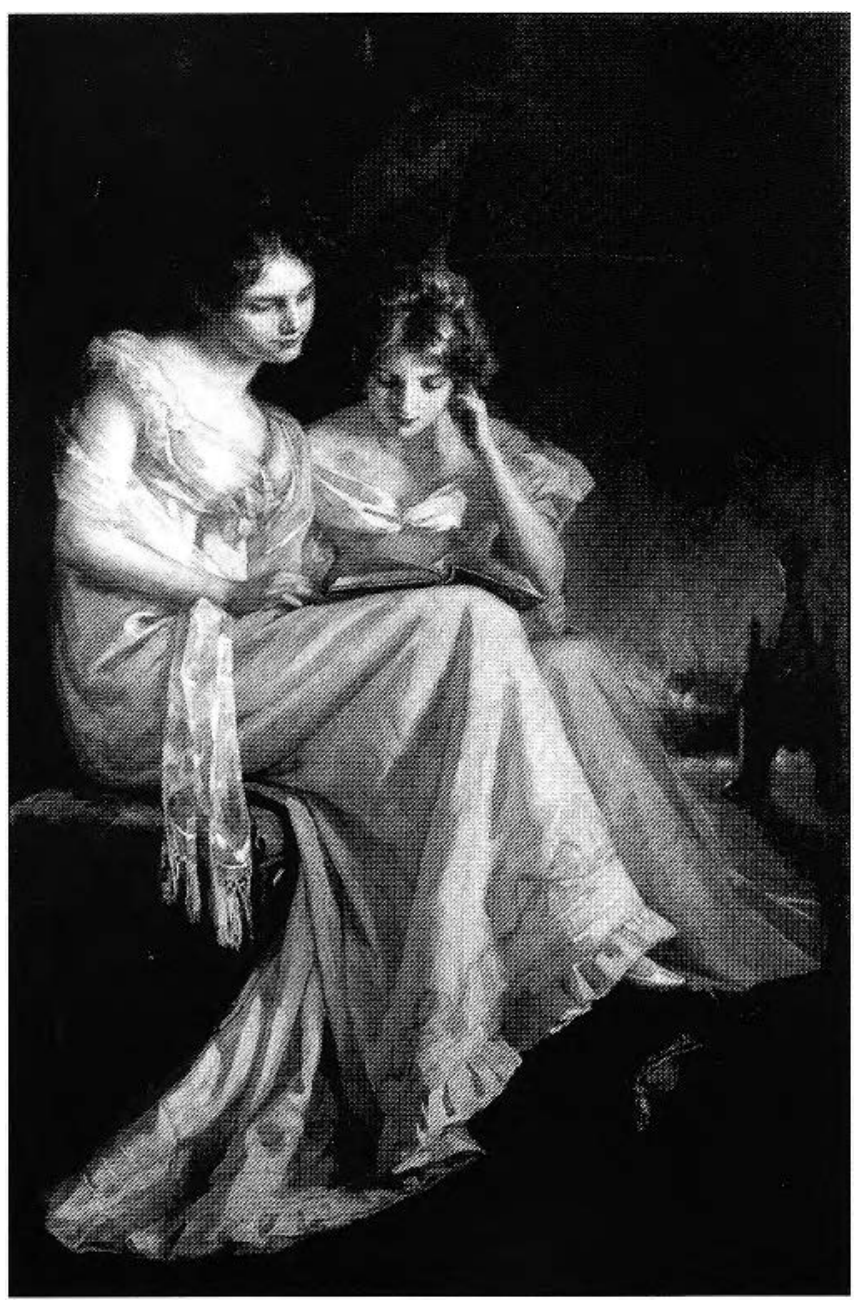

Art in London in 1890-96 and at the Académie Julian in Paris in 1896-99, and had exhibited frequently at the Royal Academy and the Paris Salon. On her return to Victoria she was in great demand as a portrait painter to upper-class circles. She also painted small, scintillating watercolour landscape sketches and large Salon paintings chiefly showing young women and girls who, although often pensively melancholy, conformed to the graceful ideals of femininity of the time (fig. 6). Grace Judge's landscapes bordered on the genre of fairy-tale illustration and on the decorative arts, another domain considered acceptable for middle-class women at the time. ${ }^{47}$

Carr understood well the attractions and rewards of these modes of painting, which she rejected only after having produced her own share of them. A few of her early watercolours and drawings remain as evidence in private collections: for example, Carr's early self-portrait (fig. 7), and a painting of her sister Alice that she exhibited in 1909 under the title The Schoolmistress and that constructs a different social milieu and
Figure 7. Emily Carr, Self-Portrait, c.1906. Watercolour, private collection (Photo: reproduced in Emily Carr, An Address, Toronto, 1955).

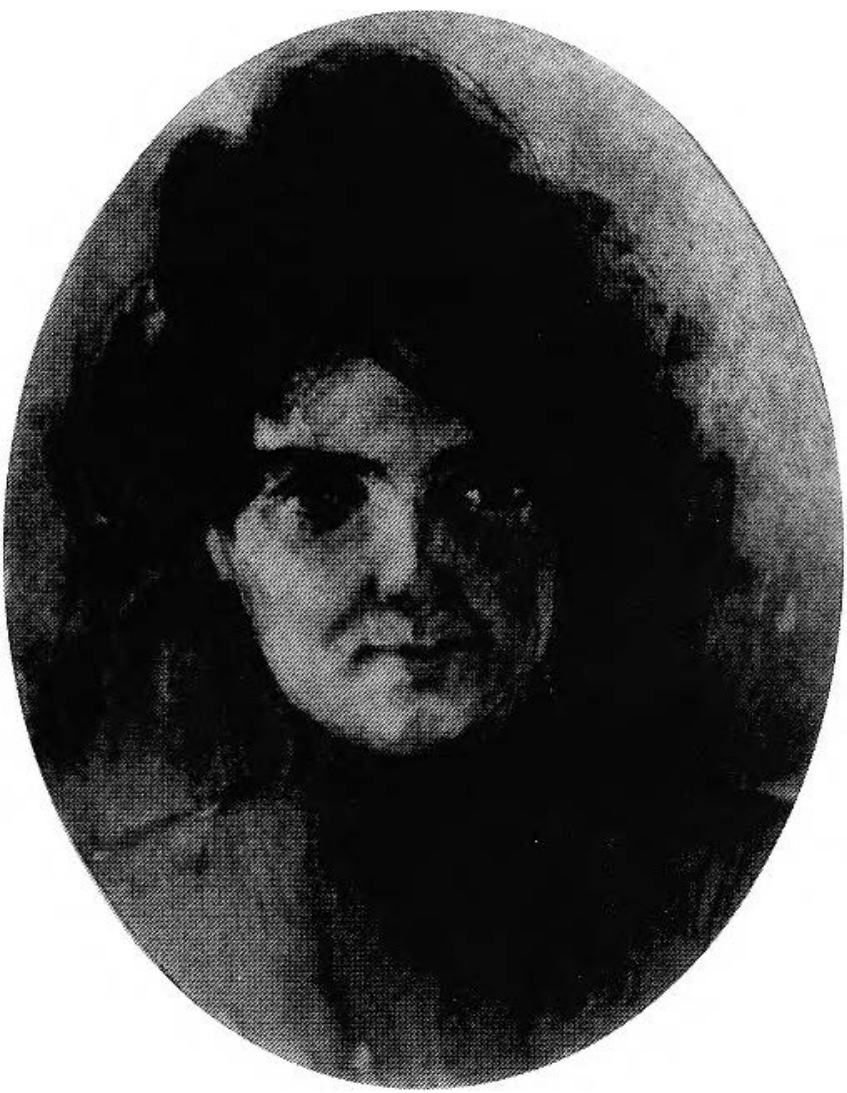

ideal of femininity than the paintings of Sophie Pemberton. ${ }^{48}$ Carr later destroyed most of this work and it has fallen out of the canon of her oeuvre, but her experience with the "feminine" genres throws into relief the singularity of her mature career. An outstanding example of her early production, the 1910 painting Lilies (fig. 8), shows that she could invest this type of work with some passion when it engaged her feelings. ${ }^{49}$ With this painting Carr has really responded to the subject, allowing herself to luxuriate in the brush marks that recreate the fine petals, the gleam of the white flowers, and the subdued glow of the porcelain vase against the shadowy ground. Wild lilies had a special meaning for Carr: in Growing Pains she singled them out repeatedly as native British Columbia wild flowers par excellence. She described them flowering just beyond the English-style perimeter hedge that her father had planted around the family property, a hedge that hemmed in Carr's activities in early life. It was to the lily field beyond the hedge that her mother took her for consolation, and it was the memory of the lilies that soothed her homesickness when she was far away from home in San Francisco. ${ }^{50}$

We can draw a parallel between Carr and the women members of the Impressionist group in Paris one generation 


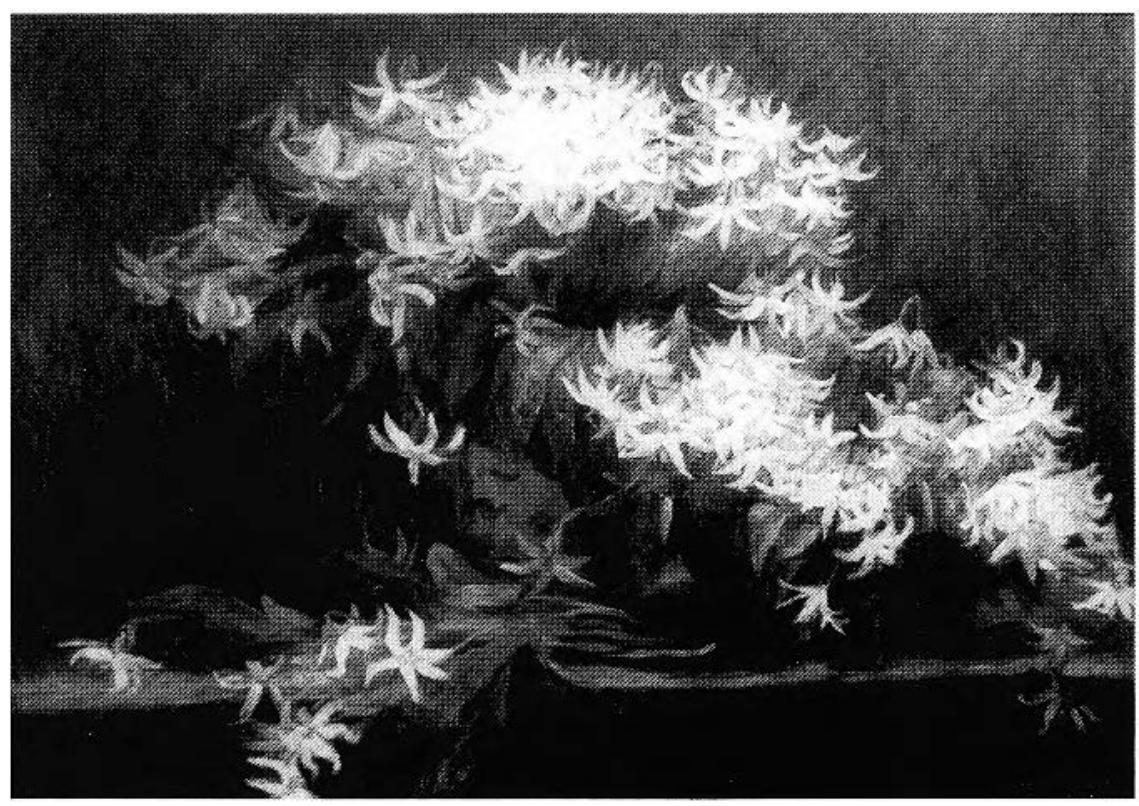

Carr's reputation as a "man-hater" reflected her impatience at and resentment of masculine authoricy and privilege.

Carr's relationship with her father also affected her relationship to the masculine. She owed a great deal to the example and encouragement of her father, as was the case with many women of her generation who were pioneers in literature, the arts or professional life. In her autobiographical writings Carr shows sharp ambivalence about her father, representing him on one hand as an unrcasonable tyrant and on the other as a man of awe-inspiring authority, moral uprightness and solid achievement. We know that Emily, the youngest of five daughters, was during her childhood her father's favourite and privileged companion. He declared that it was she who should have been the boy in the family, rather than her only

earlier, whose careers have been compared on the axis of gender with those of their male colleagues by Griselda Pollock. ${ }^{51}$ Pollock shows that the male artists of the group found their subject matter, often of a sexually risqué nature, as strollers in the public spaces of the city streets and in places of low-life entertainment, areas from which propriety excluded respectable women artists. Women Impressionists, too, were intent on painting contemporary life, but in the domestic settings that were their own domain. On this analogy, Carr became a woman artist who transgressed gender boundaries by invading the masculine world - not, in provincial British Columbia, that of the Parisian flaneur, but that of the bushwhacker, the ethnographer and the developer. ${ }^{52}$

Carr's ambitious artistic goals and her total identification with her professional career may be considered as an cxample of what Freudian theory has labelled the masculinity complex. Carr's contemporary, Karen Horney, writing in 1926, described the social subordination of women, in addition to their Oedipal fantasies, as powerful factors which might drive women away from their society's norms of femininity:

Owing to the hitherto purely masculine character of our civilization, it has been much harder for women to achieve any sublimation that would really satisfy their nature, for all the ordinary professions have been filled by men.

This again must have exercised an influence upon women's feelings of inferiority. ... It seems to me impossible to judge to how great a degree the unconscious motives for the flight from womanhood are reinforced by the actual social subordination of women. 53 surviving brother Dick, who because of his delicate health was cosseted and held on to by her mother. Emily shared her father's interest in natural history and in exploration, and became a tomboy who rejected her sisters' ladylike accomplishments. From early on her father supported her sense of worth and power, though Carr also makes it clear that as she grew older she came angrily to resent what she saw as the family's acceptance of her father's tyranny. He shook her profoundly at the age of eleven or twelve, in an episode that Carr later called the "brutal telling," when he suddenly told her the mechanics of sex and probably laid down the limits he considered suitable for her behaviour as a girl. ${ }^{54}$ Shortly after this event her mother died, and her eldest sister Edith took over as their father's chief support. The violent breach in the relationship with her father was never repaired, and he died when Emily was fifteen, leaving her the rebellious junior in a family of genteel older sisters.

From her father Carr inherited many of her values - discipline, the will to rise to a challenge, and an outlook opposed to snobbery and racial privilege - as well as her irascible temperament, but she defied him in two major respects. ${ }^{55}$ One of these was her rejection of England, the country to which he had held such a deep attachment: Carr instead would give her entire devotion to Canada and to British Columbia. The other was her rebellion against the submissive roles he expected from his wife and daughters: Carr returned from her studies in England an "Amazon," who shocked respectable Victoria society by riding her horse astride instead of side-saddle, by swearing and smoking. She now also began to compete in a masculine arena through her work. Carr's lifelong anger at rejection, and at the restrictions placed upon her, were rooted in her relationship 
with her father. But so also was her intense positive response to approval and understanding from men whom she admired. These she earned, on the shared ground of her arcistic career, from Lawren Harris through her painting, and from Ira Dilworth through her writing.

Native mothers, Mother Earth ...

While Carr resented masculine privilege and claimed the right to "paint like a man," her paintings and concerns nevertheless remained focused on themes that she shared with more conventional women artists of her day. Carr became fascinated with maternal imagery in Native carvings, and collected examples of it on her sketching trip to the North in the summer of 1928. Her visit to the Gitksan village of Kitwancool resulted in three paintings which prominently featured what Carr took to be mother and child images on totem poles. She described the poles as

... carved elaborately and with great sincerity. Several times the figure of a woman that held a child was represented.... The mothers expressed all womanhood - the big wooden hands holding the child were so full of tenderness they had to be distorted enormously in order to contain it all. ${ }^{56}$

The resulting works include Totem Mother, Kitwancool (fig. 9) and two other paintings showing poles with similar motifs. ${ }^{57}$ In Kitwancool Totems, 1928 (fig. 10), we see the "Totem Mother" pole and the one next to it, both in profile, positioned to suggest female figures watching over the village. In Klee Wyck Carr described her visit to Kitwancool, and how she was given shelter there by a Native family headed by a powerful woman of chiefly rank, Mrs. Douse. In the latter's house, shared with her married daughters and their families, there was "no rush, no scolding, no roughness." Mrs. Douse impressed Carr with her great dignity and authority. In the story Carr declares: "Womanhood was strong in Kitwancool." 58

When Carr carried out her project to make a record of Native villages and totem poles, and of Native people, during the period from 1907-13, it was predominantly women and children who appeared in her paintings. Native women are represented in her journals and tales as ideal personifications of strength and of the maternal role. In 1929 she wrote a lyrical account of her visit to the Nuu-chah-nulth village near Port Renfrew on the west coast of Vancouver Island, contrasting the tumbled-down, derelict cannery "that didn't can" with the enduring life of the Native village, where

the barefoot papooses run and squeel [sic].... And with head well up and back plumb straight Sophie barefoot walks
Figure 9. Emily Carr, Totem Mother, Kitwancool, 1928. Oil on canvas, $109.2 \times 69.3 \mathrm{~cm}$. Vancouver Art Gallery, Inv. no. 42.3.20 (Photo: Trevor Mills).

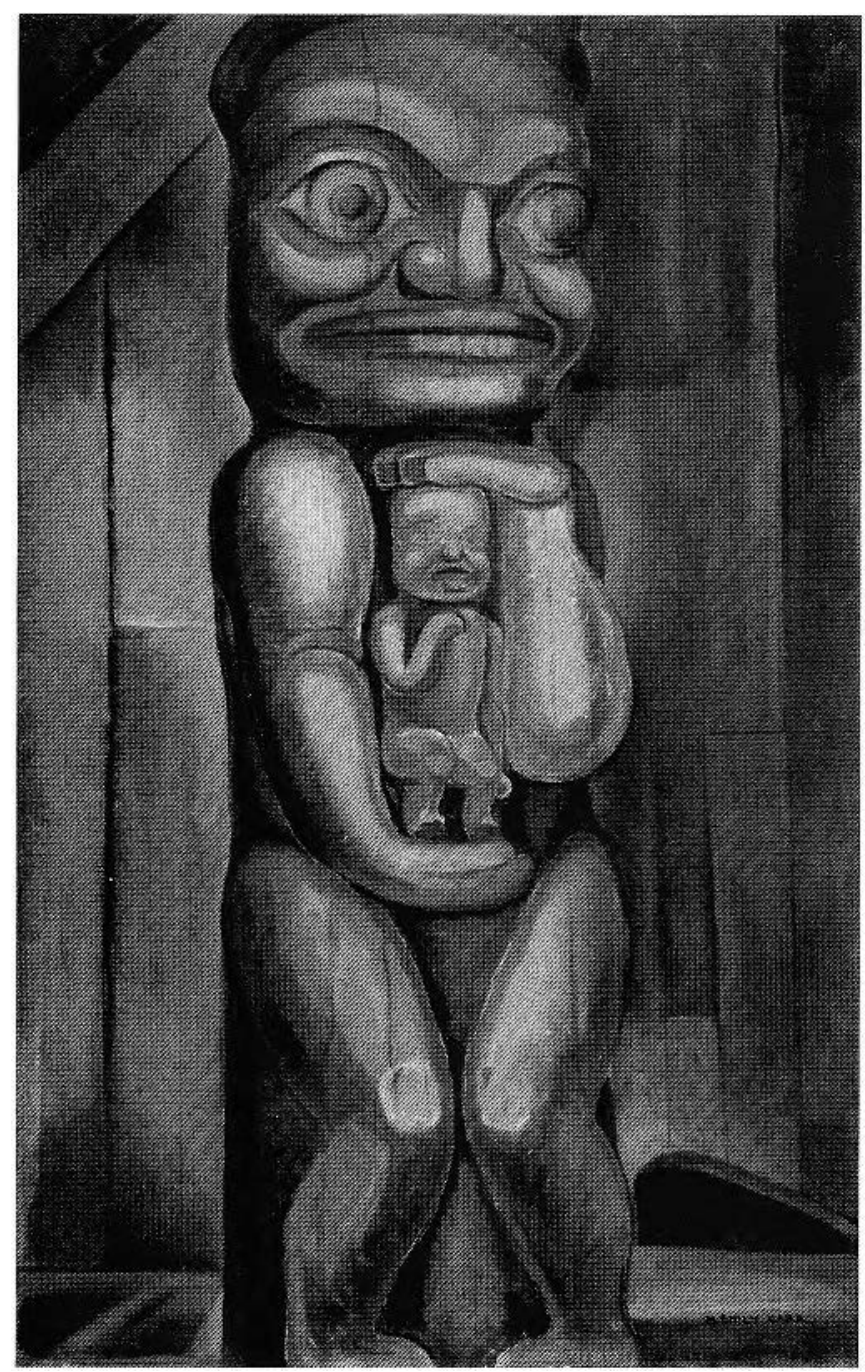

stately up the hill thro the village ... \& there is the chip chip of Jerry's tool fashioning a canoe of cedar. ... It's a gloriously peaceful hubbub not the mechanical rasping clank of the city but the mellow ring of nature knocking against nature, realities steadily holding their place in the universe. ${ }^{59}$

Carr's use of the name Sophie here recalls her long association with a Salish woman, Sophie Frank of North Vancouver, whom she got to know when she lived in Vancouver during 1906-13, and to whom she remained deeply attached for the rest of her life (fig. 11). Carr regarded Sophie Frank as the archetypal gentle, loving Indian mother, and described her as having many of the same characteristics and experiences as her own mother. Both were nurturing and affectionate, self-effacing, patient in suffering, and both had lost many babies. ${ }^{60}$ Carr's longing for her own lost mother was surely a factor in the intensity of her response to Sophie Frank's unqualified and loyal affection. In a 
Figure 10. Emily Carr, Kitwancool Totems, 1928. Oil on canvas, 105.4 $\times 68.3 \mathrm{~cm}$. Hart House, University of Toronto (Photo: Glen Lawrie).

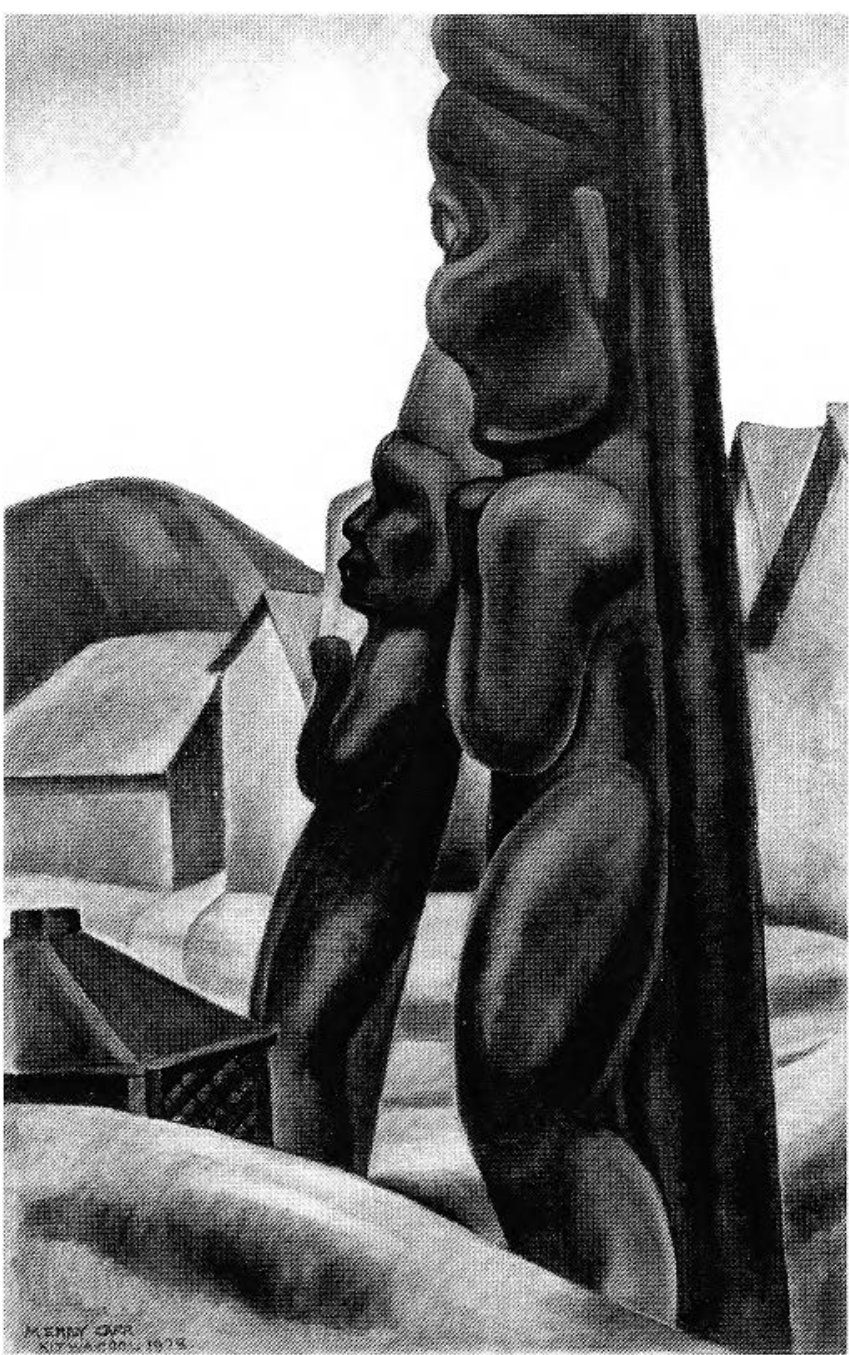

story in Klee Wyck she described times spent with her and her children and friends, times when Carr clearly basked in the family atmosphere. Sophie named one of her own children for Emily, and Emily dedicated Klee Wyck to Sophie. ${ }^{61}$ During childhood, Carr had often depended on her mother for absolution in transgression. In her adult life, when her career decisions involved masculine ambitions and an avant-gardist's isolation from conventional sociery, she sought vindication and comfort through her friendship with this Native woman, whose maternal gentleness and wisdom made her in Carr's eyes the paradigm of womanliness. At the end of her life Carr bequeathed her portrait of Sophie to her other adored friend, Ira Dilworth, with an inscription that shows that she had talked with him about Sophie's significance in her life:

The original Portrait of Sophie done probably in Vancouver around 1907 or 1908 , at my death the property of Ira
Figure II. Emily Carr, Portrait of Sophie c.1908. Watercolour on paper. Private collection (Photo: reproduced in Emily Carr, Klee Wyck, Toronto, 1941).

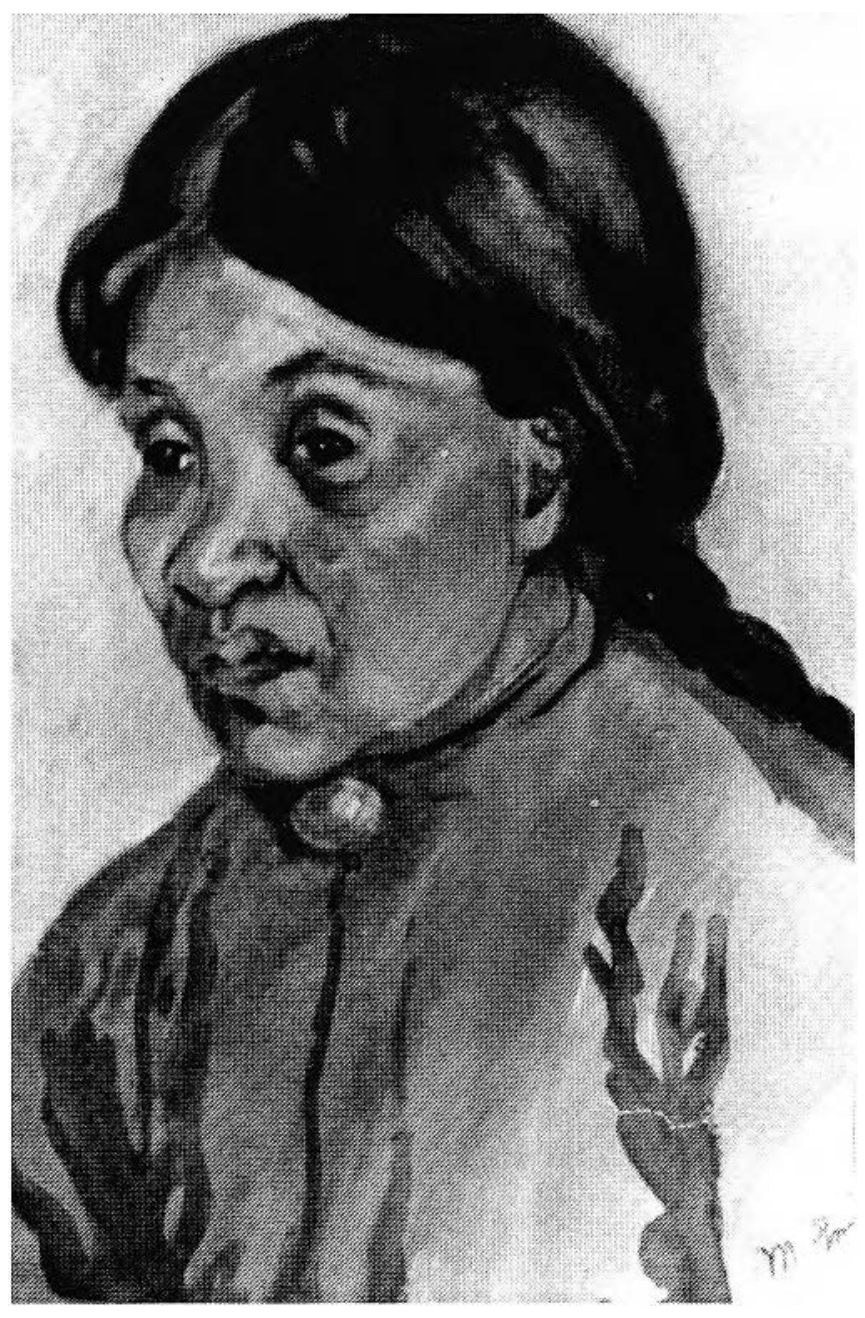

Dilworth of CBC from his love, Emily, because the life of Sophie meant so much to him. He understood her womanliness \& my love for her. To him she was more than just an Indian, she was a symbol. ${ }^{62}$

Carr's relationship with Sophie Frank can also be linked to the Dzonokwa paintings already discussed, which were made at a time of crisis in the two women's relationship. In 1927, on her journey to Eastern Canada, Emily had visited Sophie twice in North Vancouver, on the outward and again on the return journey. She wrote in her journal:

Sophie was terribly glad to see me. She'd fretted because an Indian read her there had been a train crash $\&$ she thought I might be hurt \& she couldn't sleep. Her love for me is real and mine for her. Somewhere we mect. Where? Out in the spaces there is a bond berween us where colour, crecd, 
environment don't count. The woman in us meets on common ground $\&$ we love each other. By $\&$ bye out in the spaces, who knows? what will be. ${ }^{6.3}$

She made another visit to Sophie on her way north at the start of the sketching trip of 1930 , the trip on which she would subsequently encounter the two contrasting figures of Dzonokwa. On this visit, Emily made the discovery that Sophie had succumbed to alcoholism and was working as a prostitute. ${ }^{64}$ The experience was extremely upsetting for the puritanically raised Carr. It is possible that another level of meaning in the Dzonokwa images, and in their range from the horrific to the transcendent, was Carr's search to come to terms with such darker aspects of women's sexual experience, unthinkable aspects that Sophie Frank's life forced her to confront. We saw that in Carr's story Dzonokwa transformed into a singing spirit, young and fresh, uncoarsened by violence: the friendship between Sophie and Emily was repaired and endured.

While Carr cherished memories of her dead mother and a maternal ideal embodied in Native women, there is evidence that in later life she sometimes regretted that she had not herself experienced motherhood. Around 1923, she made an attempt to persuade the parents of Carol Williams, one of her painting pupils aged about twelve with whom she felt a strong bond, to allow her to adopt the girl. ${ }^{65}$ While the parents evidently regarded this as unthinkable, they permitted Carol to spend several summers boarding with Carr. Carr treated this as though it were a case of what she believed to be a Native custom of sometimes transferring a child to a childless mother. ${ }^{66}$ Throughout the rest of her life she continued to "mother" Carol, calling her Baboo and signing herself Mom in letters, giving Carol money to travel to visit her in Victoria after she had moved away to Ontario, giving her paintings which she might sell if she was in financial need, and leaving valuable and intimate possessions, such as her own mother's wedding dress, to Carol at her death. ${ }^{67}$ In Carr's journals of her later years we also find wistful reflections on her relationship to an imagined maternal role, a role that she self-consciously sublimated through her large "family" of animals, and through metaphorical references to her creative work. ${ }^{68}$ In 1934 Carr attended lectures given in Victoria by Raja Singh, a follower of Gandhi and emissary of the Christian Indian Mission. She noted in her journal that Singh, whom she met after his lecture, assured her that God was using her to carry on his creative work. She added,

I am an expectant mother making clothes for the baby that is coming. Whether I like it or not I must paint every day so that when the child comes I will have something to clothe her in. ... The idea is God's, our part is to nourish and mother the idea $\&$ love it cherish it $\&$ in due time produce it. ${ }^{69}$
In a passage of 1937 Carr recorded,

Three now pictures are on the way, an immense wood, a wood cdge, and a woods movement. These woods movements should be stupendous, the inner burstings of growth showing through the skin of things, throbbing and throbbing to burst their way out. Perhaps if one had felt the pangs of morherhood in onc's own body onc could understand better. ${ }^{70}$

Carr's references to artistic creation through metaphors of giving birth and of maternal nurturing contrast with the metaphors of the paintbrush as penis that have been so frequently used by twentieth-century male modernist painters. They show that Carr was conscious of herself as simultaneously artist and woman, and accepted the domestic and the maternal as her domain, though in a highly nonconformist way.

Carr's landscape paintings, looked at in the light of comments in her journal, can also be seen as an arena for the projection of human relationships, prescnces and emotions. In 1936, when she moved house and made a bonfire of her early works, she reflected:

Every one brought back some memory of models or students or friends. I was surprised to see how much life work I had done. It was all pretry poor, and yet there was a certain something. I could see a fecling of the person bchind the paint. It is funny how I went back on the humans afterwards and swung out into the open, how I sought my companionship out in the woods and the trees rather than in persons. It was as if they had hit and hurt me and made me mad, and cut me off, so that I went howling back like a smacked child to Mother Nature. ${ }^{71}$

Carr's written reflections on her experience of landscape echo religious concepts, ideas of divine immanence that she found in Christianity, in Theosophy, and in Walt Whitman's transcendental mysticism. But she also often looks at her landscape motifs in terms of human dramas, and of their resolution in peace and unity. She finds there "the sweetness of Mother Nature, the nearness of God, the unity of the universe, peace, content." 72 She projects there the structures of her own nuclear family, as described in Growing Pains and in The Book of Small. The earth always is mother:

Dear Mother Earth! I think I have always specially belonged to you. I have loved from babyhood to roll upon you, to lie with my face pressed right down on you in my sorrows. I love the look of you and the smell of you and the feel of you. When I die I should like to be in you uncoffined, unshrouded, the petals of flowers against my flesh and you covering me up. ${ }^{73}$ 
In her writings trees are often personified, usually female. In 1931 she notes "two arbutus with tender satin bark, smooth and lovely as naked maidens;"74 in 1934:

lots of litcle frivolous pines, very bright and green as to tips. The wind passes over them gaily, ruffling their merry, fluffy tops and sticking-out petticoats. The little pines are very feminine and they are always on the swirl and dance in May and June. They snuggle in among the big young matrons, sassing their dignity, for they are very straight and selfrespecting, but the youngsters always tip and peep this way and that. ${ }^{75}$

This personification of trees and other elements is perhaps even clearer in her paintings: there are many images that record the hierarchies of scale, and of youth and age, that were so important in Carr's own experience as "Small." relationships are indicated by titles, for example that of the 1935 painting, Scorned as Timber, Beloved of the Sky (fig. 12), which suggests vindication of the individual in the face of social rejection. These metaphorical dynamics are formally conveyed by Carr through composition and brushwork, in the case of the painting just mentioned a wager to balance a very daringly pared down set of elements, a single spindly tree set against an animated expanse of sky that takes up four-fifths of the canvas. There is a tension in Carr's work between the exploration of landscape for objective correlates, to use T.S. Eliot's modernist term, for her own key experiences (there is an entire series of paintings of loggers' culls against the sky done during the years 1935-39), and a deliberate openness to the relations and qualities potentially mediated by a scene in front of her. As a result she avoids mere formulaic reperitiveness. ${ }^{77}$

Above all, space and the sky become for Carr the scene of God's manifestation and of her soul's free flight. She embarked on this theme after the revelation of a religious dimension in Lawren Harris's work and was further encouraged by her reading of Walt Whitman. ${ }^{78}$ In 1931, walking on Beacon Hill on a beautiful evening full of colour and life, she remarked on "two bright spots of gold peering through a black cloud and sending beams of light down. I thought they might have been God's eyes." Carr made the landscape a theatre of emotional and quasi-erotic self-abandon, of the experience of "a breath that draws your breath into its breathing, a heartbeat that pounds on yours, a recognition of the oneness of all things." 79

\section{Carr's personae?}

Carr's dedication to an art practice that encompassed exploratory subject matter and a modernist style, both territories conventionally identified as masculine, resulted at first in failure
Figure 12. Emily Carr, Scorned as Timber, Beloved of the Sky, c.1935. Oil on Canvas, $111.8 \times$ $68.4 \mathrm{~cm}$. Vancouver Art Gallery (Photo: Trevor Mills).

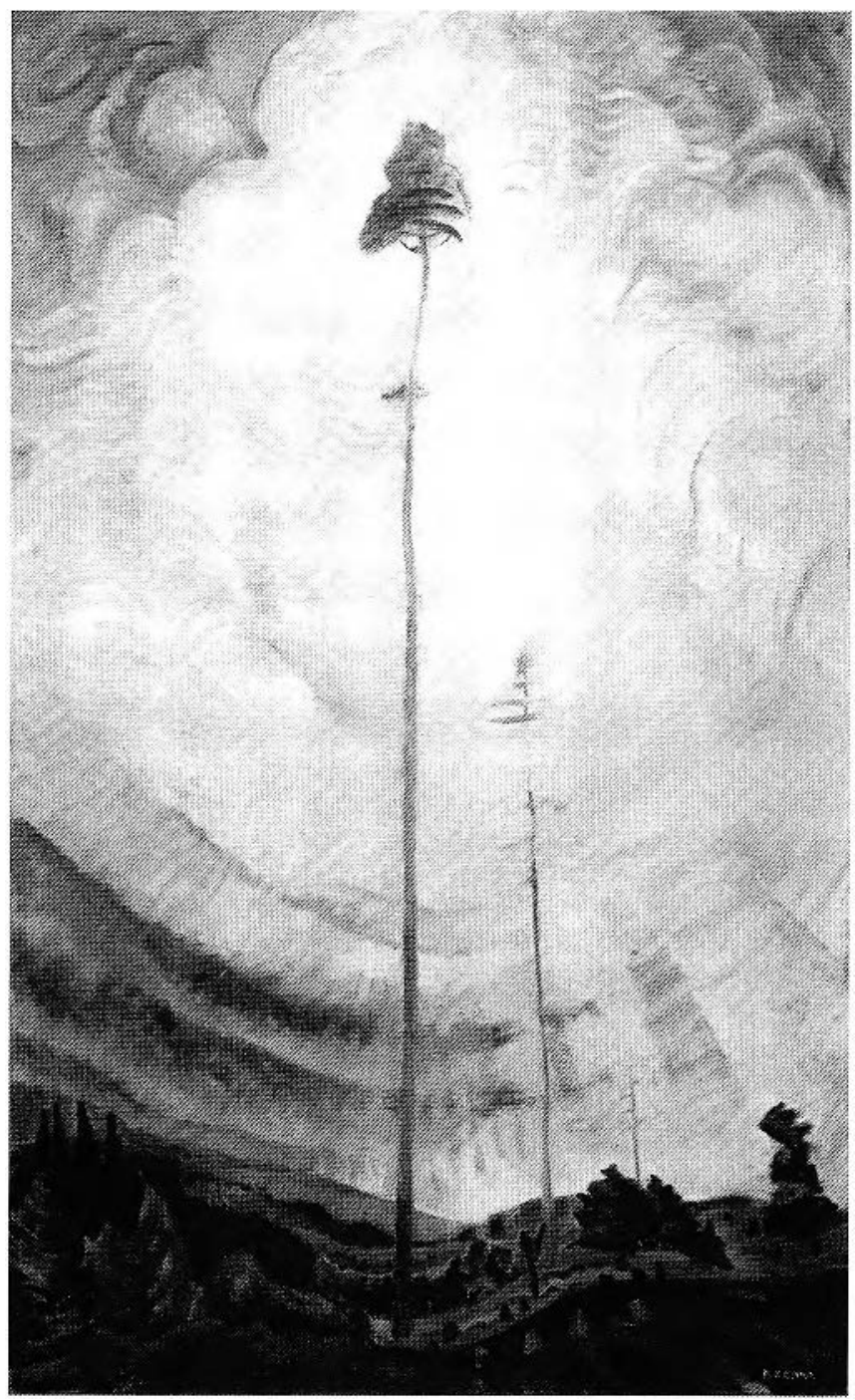

and, later in life, in fame and acknowledgment. Yet Carr's critical reception during her lifetime never directly addressed the question of her gender. This is an interesting contrast with the case of Georgia O'Keeffe, where the artist's work was interpreted as a direct expression of her sexual being to a degree that embarrassed and irritated her. O'Keeffe had no wish to be placed in a separate category as a female artist or to have her formal and intellectual interests passed over. Carr's work, too, invites discussion as an expression of female sexuality although, like O'Keeffe, Carr would have disliked such discussion. The dual reception of O'Keeffe as both a modernist and a painter of feminine sexuality was generated by a specifically American ideological agenda of proving that the United States, as the land of liberty, was the first country to produce a great woman painter. ${ }^{80}$ It was a different agenda that brought about Carr's recognition as a modernist, one that emphasized her affinity 
with what was then categorized as the "primitivism" of Northwest Coast Native peoples, in order to prove the assimilation of the "Indian" into a modern Canadian national art.

Carr's contemporary reception was none the less affected by her gender, if in a covert way. Her supporters and colleagues such as Eric Brown, Director of the National Gallery of Canada, and the painter Lawren Harris, were slow to accord her the same professional rank and rewards as members of the Group of Seven. True, her reputation was initially secured by the National Gallery of Canada with the Exhibition of Canadian West Coast Art, Native and Modern, and Eric Brown did subsequently solicit work from her for the National Gallery's Biennials and for international touring shows of Canadian art that he organized, while the Group of Seven invited her to participate in their last two shows in 1930 and $1931 .{ }^{81}$ Carr herself also submitted work after 1927 to professional organizations in the east such as the Ontario Society of Artists and the Canadian Group of Painters. As a result of the 1927 Exhibition of Canadian West Coast Art the National Gallery had bought three of her 1912 watercolours. Yet, over the next ten years, despite the fact that Carr exhibited regularly in the eastern exhibitions from which the Gallery steadily added to its already significant holdings of work by the now canonical Group of Seven, they bought none of Carr's new works. Some of her later work was finally acquired in 1937, only after Carr had a severe heart attack and friends pressured the gallery to make a purchase so that she could pay her medical bills. ${ }^{82}$

The critical commentary on Carr published by her friends and contemporaries like Lawren Harris, Ira Dilworth and Jack Shadbolt placed particular emphasis not only on her lonely struggle, but on her eccentricity, her menage of animals, and her closeness to nature. This had an effect that Scott Watson has aptly articulated:

The idea of Carr's persona as a wounded or lacking persona was constructed in her lifetime. ... This category is both privileged and damned. It's closer to nature and yer, in Jack Shadbolt's construction of her, the lack is depicted as sacrifice. And it's demonized as something he would not want to do himself. It's partly because of her own motif, her own construction of herself and the nature of her practice, but it's also because she was a woman. ${ }^{83}$

Although one of the most innovative of Canadian modernist painters, Carr, as a woman, could not be imagined by these men or by the general public as their full professional peer, nor as the acute student of international stylistic currents and the wouldbe participant in the institutional art world that she was. She becomes instead a grotesque, one of the "odds and ends" to 
quote the title of another of her paintings - odd, and an addition at the end of the Group of Seven's Canadian art movement. Recognition of her superior achievement in a broader arena came from outsiders, for whom Carr, the woman, was a remote and unknown figure. Thus it was a British authority, Eric Newton, who saw Carr's work in her studio while she lay in hospital in 1937, who awarded her the supreme accolade accessible to masculinity, that of "genius:"

If the word "genius" (a word to be jealously guarded by the critic and used only on very special occasions) can be applied to any Canadian artist it can be applied to her. ... Living among the moist mountains and giant pines of British Columbia, a country climatically different from the rest of Canada, she has had to invent a new set of conventions, a personal style of her own. Where the Eastern Canadians have been content to stylize the outward pageantry of the landscape, she has symbolized its inner meaning, and in doing so, as it were, humanized it. ... Her art is not easy to describe, and indeed her power can hardly be felt in the four works shown in London. It happens that I saw over a hundred of her paintings when I was in Victoria. To see them was rather like reading an epic. Four short quotations cannor adequately represent the cumulative effect of the whole. ${ }^{84}$

How did Carr herself see the contradictions between her work and her prescribed role as a woman? How did she regard herself as an artist? What did she take from the modernist aestheric, and what did she contribute to it? I have argued that Carr embarked on her distinctive course as a painter during her Vancouver years in the belief that Canada was a new land where the gender restrictions that had confined European women could be cast aside. In the light of Carr's actual experience, this assumption was problematic, and she was continually puzzled and hurt, particularly by the responses of those closest to her, like her sisters, who were themselves very strong women and active participants in the philanthropic movements through which many women's energies were then channeled - in what Mariana Valverde has characterized as the "age of light, soap, and water." ${ }^{85}$ The persona that Carr developed held a moral fervor similar to theirs, although her exploration and analysis of the issues of the time often led her to opposite conclusions: against missionaries and for Native traditions; against institutional religion and for an ecumenism that respected oriental and Native religions; against privilege and for those whom she saw as "workers;" against academic art and for "fresh seeing." Through her life-style she supplied herself with substitutes for those conventional areas of feminine aspiration with which she identified: animals replaced children, and so did her paintings. Photographs of her made in the 1930s, when she was in her sixties, show her aura of power and self confidence in the context of her work (fig. 13) and of sympathy and skill with animals.

This hard-won ease, as we know from her writings, was not the whole of Carr's experience. Modernist painting, with its built-in utopian agenda to envision a new order of things through its apparent access to a primal register of experience of colour and form prior to culture and to reason, gave Carr a vehicle for pursuing experiences of ecstasy and unity. But the sense of fragmentation that emerges when modern women examine their own subjectivity, through languages and literary conventions that have been codified by men, appears in the multiple personae Carr revealed in her writings: among them are "Klee Wyck," "Small," "Sophie's Em'ly" - and "T'Other Emily," as she signed herself in letters to Lawren Harris, from whom she sought help with the dark depressions and professional doubts that haunted her even after she had become one of Canada's most famous modern artists.

\section{Notes}

* A version of this essay was read at the Universities Art Association of Canada's annual conference at the University of Victoria, November 1992. It was stimulated by discussions at an Emily Carr seminar at the Vancouver Art Gallery organized in 1991 by Judith Mastai, and most particularly by issues raised by Sarah Diamond, published as "Excerpts from an Invicational Seminar on the Life and Work of Emily Carr," Collapse, no. 2 (1996), 78-121. I am indebted for fruitful comments to Jeanne Randolph, Leslie Korrick, Carol Laing, John O’Brian, Robert Linsley, Tila Kelman, Barbara Godard and Joyce Zemans.

1 British Columbia Archives (henceforth BCA), Carr Papers, Carr to Ira Dilworth Feb 14, 1942.

2 See, for example, Catherine Sheldrick Ross, "A Singing Spirit': Female Rires of Passage in Klee Wyck, Surfacing and The Diviners." Atlantis, 44, no. 1 (Autumn 1978), 87-94; Laurie Ricou, Everyday Languages: Child Languages in Canadian Literature (Vancouver, 1987); Helen Buss, Mapping Our Selves: Canadian Women's Autobiography in English (Montreal, 1993); and Stephanie Kirkwood Walker, This Woman in Particular: Contexts for the Biographical Image of Emily Carr (Waterloo, 1996).

3 Carr took a correspondence course in short fiction writing in 1926-27, and a short-story wricing course in Victoria in 1934. During 1931-34 she was encouraged by friends in eastern Canada, particularly Lawren Harris, to write both "Indian" stories and autobiographical tales. Her first book of stories, Klee Wyck, was put together in 1937 and published in 1941. See Paula Blanchard, The Life of Emily Carr (Vancouver, 1987) 165-66, 236-37, 273-75.

4 Anne Middleton Wagner, Three Artists (Three Women): Modernism and the Art of Hesse, Krasner and O'Keeffe (Berkeley, 1996), 13, 27.

5 A full discussion of Carr's representations of and relations with Northwest Coast Native cultures can be found in Gerta Moray, 
"Northwest Coast Native Culture and the Early Indian Paintings of Emily Carr," PhD thesis, University of Toronco, 1993, and idem, Unsettling Encounters: The "Indian" Pictures of Emily Carr (Vancouver, forthcoming)

6 F.B. Housser, A Canadian Art Movement; The Story of the Group of Seven (Toronto, 1926), 15. For a discussion of the social and economic context of the Group of Seven's work see Paul Walton, "The Group Of Seven and Northern Development," RACAR, XVII, no. 2 (1990), 171-79.

7 Blanchard, Life, 107.

8 Kwakwaka'wakw today replaces the earlier anthropological designation Kwakiutl for the Kwakwala speaking people of the northern Vancouver Island area

9 Emily Carr, Klee Wyck, (Toronto, 1941), 48. The Dzonokwa, in Kwakiutl tradition, is a sleepy giantess with sunken eyes and pursed lips who roams the woods. As a guardian spirit, owned as a crest by certain noble families, she is a bringer of wealth and connected in legend with the origins of the Winter Ceremonial. See Aldona Jonaitis, ed., Chiefly Feasts, The Enduring Kwakiutl Potlatch (New York, 1991), 198; and C. Lévi-Strauss, The Way of the Masks (London, 1982). Note: The spelling of Native names is given in the text according to the current usage at the American Museum of Natural History, but Carr and her contemporaries used many variant spellings.

10 Carr was at this time in her late fifties, and had spent a period of about twelve years during which she had painted very little and despaired of her career. Her financial circumstances, and a severe recession in British Columbia from 1913 on, had made it necessary for her to turn to other activities to earn her living.

11 Emily Carr, Hundreds and Thousands (Toronto, 1978), 6-7, 17 November 1927.

12 Carr, Hundreds and Thousands, 5.

13 Carr, Hundreds and Thousands, 6.

14 Carr, Hundreds and Thousands, 9.

15 Carr, Hundreds and Thousands, 5.

16 This sketch is large but is painted on two smaller sheets of paper joined together at the centre. Similar sketches on joined paper were not exhibited by Carr, but were used as the starting point for studio oil paintings. In the "Lecture on Totems" that Carr delivered at the exhibition of her documentary paintings, she explained to her audience that this figure, "with its outstretched arms and diabolical face [was] ... a Dsonokoa, or wood spirit." BCA, Carr Papers, ms "Lecture on Totems," 50-51.

17 See Emily Carr, Growing Pains: The Autobiography of Emily Carr, 2nd edn (Toronto, 1966), 29, 100

18 Carr, Growing Pains, 99-101.

19 Carol Duncan, "Virility and Domination in early Twentieth-Century Vanguard Painting," in Norma Broude and Mary D. Garrard, eds, Feminism and Art History: Questioning the Litany (New York, 1982), 293-313. For an analysis of the sexual politics of Picasso's primitivism in 1905-14, see also Hal Foster, "The 'Primitive' Unconscious of Modern Art," in Recodings: Art, Spectacle, Cultural Politics (Port Townsend, Wash., 1985), 181-208.

20 Carr, Growing Pains, 219-20.
21 Emily Carr, "Modern and Indian Art of the West Coast," Supplement to the McGill News (June 1929), 18-22. Carr at this time made an intense study of contemporary European modernist artists through books and magazines available to her, and through her Seattle contacts, particularly Mark Tobey. See Doris Shadbolt, Emily Carr (Vancouver, 1990), 49-61.

22 These are Zunoqua (1930, watercolour, Vancouver Art Gallery), and Indian Totem Pole (1930, watercolour, Mendel family collection). The other female images will be discussed later in the paper.

23 Blanchard, Life, 226 and 311, n 19.

24 Carr, Hundreds and Thousands, 155.

25 Carr, Klee Wyck, 49. The village was Gwayasdums on Gilford Island, where Carr painted the sketch of Guyasdoms d'Sonoqua in 1912.

26 Carr, Klee Wyck, 50. This figure was on a housepost at Fort Rupert, and Carr made a watercolour of it, Totem D'Sonoqua, now in a private collection (Heffel Fine Art Auction, 27 May 1999, lot 48).

27 Carr, Klee Wyck, 51.

28 See Carr, Growing Pains, 12-15, and The Book of Small (Toronto, 1966), passim

29 Maria Tippett, Emily Carr: A Biography (Toronto, 1979), 71.

30 See Laura Mulvey's discussion of the image of the phallic woman in film, in "Visual Pleasure and Narrative Cinema," Screen, 16, no. 3 (Autumn 1975), 6-18.

31 None of Erna Gunther's letters to Emily Carr have survived, but the British Columbia Archives has her correspondence with William Newcombe, a mutual friend of Gunther and Carr. See Newcombe Family Papers, Letters, BCA.

32 Carr, Klee Wyck, 57-58.

33 The episode occurred after the "brutal telling," which will be discussed below. See Carr, Growing Pains, 7-8.

34 The qualities of quest narrative in Carr's autobiographical writing were first remarked on by Blanchard, Life, 129.

35 Tamar Garb, Sisters of the Brush, Women's Artistic Culture in Late Nineteenth-Century Paris (New Haven, 1994), 105-64.

36 There is a large literature on nineteenth-century gender roles and their grounding in the concept of separate spheres for men and for women. See, for example, Susan Mendus and Jane Rendall, eds, Sexuality \& Subordination (London, 1989). For reactions by both women and men to women's entry into higher education and the professions, see Lillian Faderman, Surpassing the Love of Men: Romantic Friendship and Love Between Women from the Renaissance to the Present (New York, 1981), 178-90, 204-54.

37 Garb, Sisters of the Brush, 136, 160.

38 For Carr's teachers, see Carr, Growing Pains, 26, 46-47; Tippett, Emily Carr, 18; Blanchard, Life, 62-63. Carr mentions, however, the importance to her of "a student of the Life Class, a woman of mature years and of great ability," who explained to her that life classes were necessary as a way of going beyond surface vision, and admonished her to see beyond conventional prejudices: "Child, don't let false ideas cramp your Art." Growing Pains, 31.

39 See Tippett, Emily Carr, 21, for an early still life, and 31, for a sketch of Ucluelet.

40 Carr received several proposals of marriage around 1899-1903 
from Mayo Paddon, a Victoria man she considered a sympathetic and appcaling friend. She rejected him, however, partly because of her continuing love for an unnamed man with whom she had had a brief liaison earlier in Victoria but who did not requite her emotional attachment. Her attitude to marriage was also coloured by her knowledge that it would prevent her from completing her studies in England and pursuing her profession as an artist with full commitment. She commented on the difficult predicament of a woman artist with children whom she had known in San Francisco in Growing Pains, 55-58. For the prevailing view at this time that a professional life was incompatible with the duties expected of a woman in marriage, see Faderman, Surpassing the Love of Men, 204-30.

41 See Emily Carr, Pause (Toronto, 1953), 17-22, 57-58; Carr, Growing Pains, 190; Elaine Showalter, The Female Malady: Women, Madness, and English Culture, 1830-1980 (London, 1985), 121-44.

42 The words of physician George Miller Beard, cired in Showalter, The Female Malady, 135.

43 Cf. Showalter, The Female Malady, 143, for a 1905 description of the treatment of a female neurasthenic in England.

44 Carr, Growing Pains, 105, 121.

45 Carr, Growing Pains, 103. The name means "smiling one."

46 In Paris Carr deliberately avoided the segregated studios for female students, enrolling instead at the Académie Colarossi, and selecting private study with teachers who interested her, like New Zealander Fiances Hodgkins.

47 For Sophic Pemberton see Nicholas Tuclc, Sophia Theresa Pemberton (1869 - 1959) (Victoria, 1978); for Grace Judge, see Maria Tippett and Douglas Cole, From Desolation to Splendour: Changing Perceptions of the British Columbia Landscape (Toronto, 1977).

48 The Schoolmistress is reproduced in Doris Shadbolt, The Art of Emily Carr (Vancouver, 1979), 25.

49 Lilies (1910, oil on canvas, private collection, Victoria) was preserved because Carr gave it to her sister Elizabeth.

50 Carr, Growing Pains, 7-8, 27-28.

51 Griselda Pollock, "Modernity and the Spaces of Femininity," in idem, Vision and Difference (London, 1988), 50-90.

52 Carr echocd the rhetoric that was uscd to promote the Group of Seven when she described her own activities. She wrote soon after meeting them, "It must be understood that my collection of Indian pictures was not done in a comfortable studio from a sketch or two: that can't be done. You have to go out and wrestle with the elements." Emily Carr, "Modern and Indian Art," 21.

53 Karen Horney, "The Flight From Womanhood, The Masculinity Complex in Women as Viewed by Men and Women," in Jean Baker Miller, ed., Psychoanalysis and Women (Harmondsworth, 1973), 19-21.

54 Cf. Blanchard, Life, 53-55. Carr recalled this distressing episode in an unpublished section of her journal of 1935: "Coming near the end of a big family I could only know' a cross gouty sexy old man who hurt and disgusted me. I resented his omnipotence, his selfishness and I was frightened of him. He knew he had hurt \& frightened me telling me things a happy innocent child should not hear and tclling them in a low \& blatant manner ... I couldn't forgive father I just couldn't for spoiling all the loveliness of life with that bestial brutalness of explanation filling me with horror instead of gently explaining the glorious beauty of re-production the holiness \& joy of it." BCA, Carr Papers, ms. Journals, 1935 Easter Monday. This account has been variously interpreted by Carr's biographers. While admitting that the sources are too fragmentary to allow a reliable verdict, Maria Tippett has speculated that Carr's illness of 1.903, allegedly diagnosed as hysteria, had its origins partly in "whatever happened between Emily and her father - perhaps unmentionable intimacies of conversation or gesture, perhaps somcthing more or something less ..." and that this resulted in what she considers as "Carr's sexual frigidity." Tippett, Emily Carr, 58. I agree with Blanchard, Life, 91, that Tippett's conclusion that Carr suffered from hysteria and frigidity because of this episode is an oversimplification. It should be borne in mind that Carr's first reference to the "brutal telling" in 1935 was occasioned by discovering her father's early journal, and that she continues: "That diary has given me an entirely new slant on Father. ... Now ... I can see he must have been a fine young man, strong and brave honest kindly and energetic plenty of perseverance and plenty of pluck. He seemed fond of his own parents too. His experiences \& impressions of the New World are most interesting but he remained an English ultra Englishman till he died." Although she again cxpressed anger at her father's "brutal telling" in a reference to the event in a letter to Ira Dilworth, written when she was working on her autobiography (BCA, Carr Papers, Carr to Dilworth, "Tuesday," n.d. [1942-43]), it is significant that the 1935 journal entry also acknowledges common ground with her father and a shift towards the more appreciativc attitude to him found in her later aurobiographical books, Growing Pains and The Book of Small.

55 Carr described the Victoria of her childhood in The Book of Small. Her father, a prosperous importer-wholesaler, was a member of the earliest settler group, but unlike many other successful pioneer citizens he did not move his family up the hill into the smart area of Victoria, and he refused to send his younger daughters to private academies, feeling that they would get a better intellectual education in the public school. Carr, Book of Small, pp. 10, 116-17, 168. Richard Carr also recorded in his journals his disgust with colonial mistreatment of Natives. See Blanchard, Life, 14-15.

56 Carr, Klee Wyck, 143.

57 Totem Mother (1928, oil on canvas) is in the Vancouver Art Gallery, Base of a Kitwancool Pole (1928, oil on canvas) in the GlenbowAlberta Institute, Calgary, and Corner of Kitwancool Village (1928, probably retouched 1941, oil on canvas) in the McMichael Canadian Art Collection, Kleinburg. There is some doubt whether the pole carvings were all morher and child images, or in some cases images of mythical guardian spirits holding their protégés. According to Marius Barbeau, the pole of Weerhae from which Carr painted Totem Mother shows a spirit figure which originally had had a curved hawk's beak in place of a nose, a feature that had fallen off when Carr saw it. See Marius Barbeau, Totem Poles of the Gitksan, National Muscum of Canada Bulletin No. 61 (Ottawa, 1929), 117. Howcver, the story of an ancestress of Weerhae, who 
had been kidnapped by a mountain eagle whom she courageously forced to relinquish her and her semi-human children, is portrayed on several of the poles, and some of the mother and child images at Kirwancool refer to this.

58 "Kitwancool," Klee Wyck, 143. Carr painted a portrait of Mrs. Douse (1928, watercolour, BCA), and after her return to Victoria wrote to her, and sent her paintings of her poles; Carr, Klee Wyck, 149.

59 BCA, Carr Papers, ms. Journals 1929.

60 Carr's mother, who ultimately succumbed to tuberculosis, had borne three sons who died in infancy. A fourch, Richard, who was Carr's junior by three years, died of tuberculosis at the age of twenty-four. The case of Sophie Frank was even more tragic. Carr recorded that of her twenty-one children none survived her. Tuberculosis was a major cause of child mortality in the Native population of British Columbia.

61 Carr, Klee Wyck, 22-31.

62 Inscribed in Carr's hand on the backing of the frame of Portrait of Sophie (1907-8, watercolour, private collection). "The life of Sophie" was Carr's initial title for the story "Sophie" in Klee Wyck.

63 BCA, Carr Papers, ms. Journals, 25 December 1927.

64 BCA, Carr Papers, ms. Journals, 19 August 1930.

65 Carol Pearson, Emily Carr as I Knew Her (Toronto, 1954), 39-48.

66 In her manuscripe "Lecture on Totems" (1913), Carr described what she felt was an admirable aboriginal custom, that a childless woman might be given a child by a female relacive or friend. She commented, "How many white mothers, though they might gricve for another's sorrow would ever dream of such a sacrificc," BCA, Carr Papers, "I.ecture on Totems," 39.

67 Author's interview with Mrs. Carol Pearson (née Williams), June 1989.

68 After moving to Vancouver, Carr collected animals to make up a household of her own which she labelled, in a phorograph of around 1906, her "whole [damn] family" (reproduced in Tippett, Emily Carr, 70). During the years 1914-32 she bred first sheep dogs and then Belgian griffons to supplement her income.

69 BCA, Carr Papers, ms. Journals, 3 February 1934.

70 Carr, Hundreds and Thousands, 295.

71 Carr, Hundreds and Thousands, 219.

72 BCARS, Carr Papers, "Renfrew, August 14, 1929," cited in T"ippctt, Emily Carr, 172.
73 Carr, Hundreds and Thousands, 101

74 Carr, Hundreds and Thousands, 25.

75 Carr, Hundreds and Thousands, but noce also her caution against too much anthropomorphizing, 146.

76 Carr developed the persona of Small in letters to Ira Dilworth while she was writing memoirs of her childhood.

77 See, for example, Shadbolt, The Art of Emily Carr, plates 109, 110, $115,116,117,150$.

78 Carr, Hundreds and Thousands, 54.

79 Carr, Hundreds and Thousands, 28. 215.

80 See B. Lynes, O'Keeffe, Stieglitz and the Critics (Ann Arbor, 1989).

81 See the invaluable data on Carr's exhibition history in Edyche Hembroff-Schleicher, Emily Carr: The Untold Story (Saanichton, 1978), $301-402$.

82 By 1936 the National Gallery had accuired the following numbers of works by members of the Group of Seven and Tom Thomson: Thomson 30, J.E.H. MacDonald 17, A.Y. Jackson 9, A. Lismer 8, L. Harris 7, F. Varley 7, F. Carmichael 3. In 1930 the National Gallery bought George Pepper's Totem Poles, Kitwanga 1929, and Edwin Holgate's Totem Poles Kitseuklas 1927. In 1931 and 1932 Carr hoped they might buy current work by her, and was disappointed. In 1933-35 the NGC suspended contemporary purchases because of the Depression, but resumed in 1936 with purchases from Carmichael, Harris, Lismer, C. Schacfer, Varley. Carr was still only represented by the three 1912 watercolours purchased by the Gallery in 1928. Figures are taken from R.H. Hubbard, The National Gallery of Canada, Catalogue of Paintings and Sculpture, Volume III: Canadian School (Ottawa, 1975).

83 "Excerpts from an Invicational Seminar on the Life and Work of Emily Carr," Collapse, no. 2 (1996), 84-85.

84 Eric Newton reviewing an exhibition of Canadian painting at the Tate Gallery, "Canadian Art Through English Eyes," Canadian Forum (February 1939), 345. Carr was discussed by younger critics in the 1930s, such as Graham Mclnnis, Donald Buchanan and Roger Stanier, on formalist grounds as a rare phenomenon in Canada, an experimental modernist who had forged an original artistic style. For Carr's reception as a modernist painter, see Moray, "Northwest Coast," 37-49.

85 See Mariana Valverde, The Age of Light, Soap and Water: Moral Reform in English Canada, 1885-1925 (Toronto, 1991). 